OPEN ACCESS

Edited by:

Peter Kalivas,

Medical University of South Carolina,

United States

Reviewed by:

Sammanda Ramamoorthy,

Virginia Commonwealth University, United States

Ryan K. Bachtell,

University of Colorado Boulder,

United States

*Correspondence:

Tamara J. Phillips

phillipt@ohsu.edu

Specialty section: This article was submitted to

Psychopharmacology,

a section of the journal

Frontiers in Psychiatry

Received: 15 June 2021 Accepted: 02 August 2021

Published: 26 August 2021

Citation:

Phillips TJ, Roy T, Aldrich SJ, Baba H,

Erk J, Mootz JRK, Reed C and

Chesler EJ (2021) Confirmation of a

Causal Taar1 Allelic Variant in Addiction-Relevant Methamphetamine

Behaviors.

Front. Psychiatry 12:725839. doi: 10.3389/fpsyt.2021.725839

\section{Confirmation of a Causal Taar1 Allelic Variant in Addiction-Relevant Methamphetamine Behaviors}

\author{
Tamara J. Phillips ${ }^{1,2 \star}$, Tyler Roy ${ }^{3}$, Sara J. Aldrich ${ }^{1}$, Harue Baba ${ }^{1}$, Jason Erk ${ }^{1}$, \\ John R. K. Mootz ${ }^{1}$, Cheryl Reed ${ }^{1}$ and Elissa J. Chesler ${ }^{3}$
}

${ }^{1}$ Department of Behavioral Neuroscience and Methamphetamine Abuse Research Center, Oregon Health \& Science University, Portland, OR, United States, ${ }^{2}$ Veterans Affairs Portland Health Care System, Portland, OR, United States, ${ }^{3}$ The Jackson Laboratory and Center for Systems Neurogenetics of Addiction, Bar Harbor, ME, United States

Sensitivity to rewarding and reinforcing drug effects has a critical role in initial use, but the role of initial aversive drug effects has received less attention. Methamphetamine effects on dopamine re-uptake and efflux are associated with its addiction potential. However, methamphetamine also serves as a substrate for the trace amine-associated receptor 1 (TAAR1). Growing evidence in animal models indicates that increasing TAAR1 function reduces drug self-administration and intake. We previously determined that a non-synonymous single nucleotide polymorphism (SNP) in Taar1 predicts a conformational change in the receptor that has functional consequences. A Taar ${ }^{m 1} \mathrm{~J}$ mutant allele existing in DBA/2 J mice expresses a non-functional receptor. In comparison to mice that possess one or more copies of the reference Taar 1 allele (Taar $1^{+/+}$or Taar $1^{+/ m 1} \mathrm{~J}$ ), mice with the Taar $1^{m 1 \mathrm{~J} / m 1 \mathrm{~J}}$ genotype readily consume methamphetamine, express low sensitivity to aversive effects of methamphetamine, and lack sensitivity to acute methamphetamine-induced hypothermia. We used three sets of knock-in and control mice in which one Taar1 allele was exchanged with the alternative allele to determine if other methamphetamine-related traits and an opioid trait are impacted by the same Taar1 SNP proven to affect MA consumption and hypothermia. First, we measured sensitivity to conditioned rewarding and aversive effects of methamphetamine to determine if an impact of the Taar1 SNP on these traits could be proven. Next, we used multiple genetic backgrounds to study the consistency of Taar1 allelic effects on methamphetamine intake and hypothermia. Finally, we studied morphine-induced hypothermia to confirm prior data suggesting that a gene in linkage disequilibrium with Taar1, rather than Taar1, accounts for prior observed differences in sensitivity. We found that a single SNP exchange reduced sensitivity to methamphetamine conditioned reward and increased sensitivity to conditioned aversion. Profound differences in methamphetamine intake and hypothermia consistently corresponded with genotype at the SNP location, with only slight variation in magnitude across genetic backgrounds. Morphine-induced hypothermia was not dependent on Taar1 genotype. Thus, Taar1 
genotype and TAAR1 function impact multiple methamphetamine-related effects that likely predict the potential for methamphetamine use. These data support further investigation of their potential roles in risk for methamphetamine addiction and therapeutic development.

Keywords: aversion, CRISPR-Cas9, hypothermia, knock-in, morphine, pleiotropic, selective breeding, two-bottle choice

\section{INTRODUCTION}

Considerable research has focused on drug use disorders as motivational disorders involving inherent or drug-induced reward pathway function. Human and animal research supports a critical role for circuitry underlying sensitivity to rewarding and reinforcing drug effects in risk for continued use, neuroadaptation and relapse. Less is known about factors that reduce risk for addiction such as, for example, the protective role of sensitivity to aversive or adverse drug effects. Although there is important research in this area for alcohol (1-4), it has not been a focus of psychostimulant research or therapeutic development for psychostimulant addiction. To address initial sensitivity to drug aversive effects in humans requires knowledge of initial drug effects and the inclusion of individuals in studies who have tried a drug, but did not continue to use because they found the effects to be unpleasant. This is not the typical research performed in the addiction field; rather individuals suffering from a substance use disorder, or with a significant history of drug use, are compared to individuals with a low to modest drug history. Concerns about potential long-term consequences on behavior and in the brain, of even relatively low-level exposure to drugs like methamphetamine (MA) (5-14), raise concerns about conducting such research in drug-naïve humans. However, the study of drug avoiders could lead to the identification of a new class of therapeutics. Animal models of drug use have an important role in this area of study, because drug history can be controlled and initial responses readily measured.

Bidirectional selective breeding has the explicit goal of creating animal lines that exhibit a low vs. high level of a particular characteristic. We bred mice for level of voluntary MA intake and created MA high drinking (MAHDR) and MA low drinking (MALDR) lines of mice that consume binge-like levels of MA or avoid consuming MA, respectively (15-18). Using this model, we determined that a single nucleotide polymorphism (SNP) at position 229 in the trace amine-associated receptor 1 gene (Taar1) accounts for $60 \%$ of the heritable variance in MA intake (19-21). The non-synonymous SNP (rs33645709) is found in DBA/2J mice sourced from The Jackson Laboratory (JAX), but not in DBA/2 mice sourced from other suppliers (22) or in any of the 28 other strains that have been genotyped at this genetic location $(23,24)$. This coding variant changes a proline to a threonine in the second transmembrane domain of the receptor (24). Multiple lines of evidence, beginning with quantitative trait locus mapping and culminating in the use of a CRISPR-Cas9-derived knock-in (KI) model on the MAHDR background, definitively determined that this Taar1 SNP impacts level of MA consumption (21). Thus, mice homozygous for the
Taar $1^{m 1 J}$ allele consume more MA on average than mice that possess one or two copies of the reference Taar $1^{+}$allele.

In addition to identifying genetic differences related to the bidirectional selection response, selectively bred lines provide information about genetically correlated traits, defined as phenotypes that are impacted by one or more of the genes that influence the selection trait. Several MA-related traits reliably differentiate the MA drinking (MADR) lines. These include rewarding and aversive traits, as well as a physiological trait, MA-induced hypothermia, proposed to be among the aversive effects of MA that inhibit MA intake $(20,25,26)$. Herein, we report studies performed in three sets of matched KI and control line mice in which one Taarl allele was exchanged with the alternative allele. First, MAHDR-Taar $1^{+/+}$KI and control mice were studied for tastant intake and preference, and sensitivity to two traits hypothesized to be pleiotropically influenced by Taar1: sensitivity to MA-induced conditioned place preference and conditioned taste aversion. Based on previous findings (16, $18,21,22,27)$, we predicted that the KI and control mice would not differ in saccharin or quinine intake or preference, KI of the Taar ${ }^{+}$allele would decrease sensitivity to MA-induced conditioned place preference, and KI of the Taar $1^{+}$allele would increase sensitivity to MA-conditioned taste aversion. Next, KI mice generated on the MADR progenitor C57BL/6J and DBA/2J background strains were studied for MA intake and MA-induced hypothermia to examine replication of Taarl effects on different genetic backgrounds. These traits have already been confirmed to be impacted by Taar1 in the MAHDR KI and control lines (21).

Finally, previous data in MADR mice suggest that a difference in sensitivity to morphine-induced hypothermia was not a pleiotropic effect of Taar1, but more likely due to a linked polymorphism (25). To confirm this, we examined this trait in the MAHDR-Taar $1^{+/+} \mathrm{KI}$ and control mice and predicted comparable morphine-induced hypothermia.

\section{MATERIALS AND METHODS}

\section{Subjects}

Subjects were male and female MAHDR-Taar1 ${ }^{+/+}$KI, DBA/2JTaar $1^{+/+} \mathrm{KI}, \mathrm{C} 57 \mathrm{BL} / 6 \mathrm{~J}-$ Taar $1^{m 1 J / m 1 J} \mathrm{KI}$, and control lines matched to each KI line (MAHDR-Taar1 ${ }^{m 1 J / m 1 J}$, DBA/2J$\operatorname{Taar1}^{\mathrm{m1} / \mathrm{m} 1 \mathrm{~J}}$, and C57BL/6J-Taar1 ${ }^{+/+}$). The MAHDR KI mice were created at the Oregon Health \& Science University Transgenic Mouse Models Shared Resource, utilizing CRISPRCas 9 technology to replace the Taar $1^{m 1 J}$ allele with the reference Taar $1^{+}$allele; controls were derived from those mice in which the Taar $1^{m 1 J}$ allele was not successfully excised and replaced; thus, they retained the Taar $1^{m 1 J / m 1 J}$ genotype. Details can be 
found in Stafford et al. (21). The identical process was applied at JAX (Bar Harbor, ME, USA) to generate the same KI on a pure $\mathrm{DBA} / 2 \mathrm{~J}$ inbred strain background, or to replace the reference Taar $^{+}$allele with the Taar1 ${ }^{m 1 J}$ allele on a pure C57BL/6J inbred strain background.

Mice participating in the current studies were either born within the VA Portland Health Care System (VAPORHCS) Veterinary Medical Unit or within a breeding colony at JAX; location for each study is indicated in experiment descriptions. Breeders (pairs at VAPORHCS; harems at JAX) were maintained in standard acrylic plastic shoebox cages on corncob bedding (The Andersons, Maumee, Ohio; VAPORHCS) or pine shavings (Hancock Lumber, Bethel, Maine; JAX), with wire lids and filter tops. Breeding cages resided on Thoren racks under a standard 12:12 light:dark cycle, and mice were weaned at $21 \pm 2$ days of age into same-sex groups of 2-4 per cage. During breeding and experiments, mice were maintained in climate-controlled rooms under a standard 12:12 light:dark cycle with lights on at $0600 \mathrm{~h}$, and free access to water (tap water at the VAPORHCS; filtered and acidified at JAX) and rodent block food (Purina 5001 or 5LOD PicoLab Rodent Diet; Animal Specialties, Woodburn, Oregon at the VAPORHCS; NIH315K52 chow Lab Diet 6\%PM Nutrition, St. Louis MO, USA at JAX); exceptions are noted in experimental methods. All animal care and testing procedures were approved by the VAPORHCS or JAX Institutional Animal Care and Use Committee, and were conducted in compliance with the National Institutes of Health Guidelines for Care and Use of Laboratory Animals. Group sizes for each experiment are given in the figure captions.

\section{Genotyping}

All KI and control offspring used in these studies were genotyped for Taarl using an rtPCR method developed in our laboratory for the relevant Taar1 SNP, based on a standard Taqman (ThermoFisher Scientific) assay in which fluorescent probes were used for differentiation (22).

\section{Drugs}

$(+)$ Methamphetamine hydrochloride was purchased from Sigma-Aldrich (St. Louis, MO, USA) or obtained from the National Institutes of Health, National Institute on Drug Abuse drug supply program (Rockville, MD, USA) and dissolved in tap water for drinking or in sterile $0.9 \%$ saline (Baxter Healthcare Corp., Deerfield, IL, USA) for injection. Sodium chloride for conditioned taste aversion studies, and saccharin and quinine for novel tastant intake studies, were purchased from SigmaAldrich and dissolved in tap water. Morphine was obtained from the NIDA Drug Supply program (Rockville, MD, USA) and dissolved in sterile saline. Saline vehicle served as a 0 dose control treatment for MA and morphine injection studies. All injections were delivered intraperitoneally (IP) in a volume of $10 \mathrm{ml} / \mathrm{kg}$.

\section{Experiment 1: Novel Tastant Intake and Preference in MAHDR-Taar1 ${ }^{+/+} \mathrm{KI}$ and MAHDR-Taar1 ${ }^{m 1 J / m 1 J}$ Control Mice}

We characterized saccharin (SACC) and quinine (QUIN) intake and preference to investigate whether a difference in tastant intake or preference corresponds with the difference in MA intake found in a previous study between the MAHDR-Taar $1^{+/+}$ $\mathrm{KI}$ and MAHDR-Taar $1^{\mathrm{mlJ} / \mathrm{m} 1 \mathrm{~J}}$ control mice (21). This study was conducted at the VAPORHCS using methods consistent with our previous studies in the MADR mice $(16,18)$. Male and female mice were weighed, singly-housed, and given access to two waterfilled 25-ml graduated cylinders fitted with stoppers and sipper tubes for 2 consecutive days to familiarize them with drinking fluid from these tubes. Using a counterbalanced design, mice were then offered water vs. SACC and then water vs. QUIN or the two tastants in the alternate order. Tastants were offered $24 \mathrm{~h} /$ day in two increasing concentrations for 4 days each and mice were weighed every 4 days; therefore, the two-bottle choice tastant phase included days 3-18. The positions of the water and tastant tubes were alternated every 2 days, the SACC concentrations were 1.6 and $3.2 \mathrm{mM}$, and the QUIN concentrations were 0.015 and $0.03 \mathrm{mM}$, consistent with our previous studies $(16,18)$. Consumption was measured each day in $\mathrm{ml}$. Mice were tested at an average age of $81 \pm 1$ days, with a range of 77-87 days.

\section{Experiment 2: MA-Induced Conditioned Place Preference Testing in MAHDR-Taar1 ${ }^{+/+} \mathrm{KI}$ and

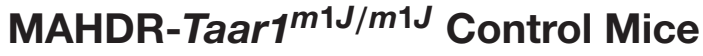

Group housed (2-4 per cage) male and female MAHDRTaar $^{+/+}$KI and MAHDR-Taar $1^{m 1 J / m 1 J}$ control mice were tested for sensitivity to conditioned place preference induced by $0.5 \mathrm{mg} / \mathrm{kg} \mathrm{MA}$, a dose that has produced consistent preference in MAHDR and no preference in MALDR mice $(16,18)$. This study was conducted at the VAPORHCS using our established unbiased place conditioning procedure. Custom-built conditioning boxes $(30 \mathrm{~cm} \times 15 \mathrm{~cm} \times 15 \mathrm{~cm}$; San Diego Instruments, San Diego, CA USA) were housed in sound attenuating, illuminated and ventilated chambers. Each conditioning box had a removable central black wall used to sequester the animal to the left or right half of the chamber during conditioning trials; the wall was removed during preference tests. Removable floor panels with unique textures served as conditioning cues. One floor was composed of $2.3 \mathrm{~mm}$ stainless steel rods mounted $6.4 \mathrm{~mm}$ apart (the "grid" floor); the other was a stainless steel sheet with $6.4 \mathrm{~mm}$ round holes on $9.5 \mathrm{~mm}$ staggered centers (the "hole" floor). Animal location was detected by photocell beam interruptions and automatically converted to time spent on a particular floor type; photocell beam interruptions were also recorded as a measure of locomotor activity.

The study began on a Monday and excluded weekends, and mice were returned to group housing (2-4 per cage) each day after testing. Mice were moved to the procedure room each day $1 \mathrm{~h}$ before conditioning or testing. Initial preference for the cues was determined in a 30-min test; mice were injected with saline immediately prior to placement in the box. Beginning 
$24 \mathrm{~h}$ later, there were 12 alternating conditioning trials (one daily), six immediately after saline, and six immediately after 0.5 $\mathrm{mg} / \mathrm{kg}$ MA treatment that were $15 \mathrm{~min}$ in duration. Half of the mice had MA paired with the grid floor and half with the hole floor, with left/right placement of floor types counterbalanced. A 30-min "drug-free" preference test was performed the day after the last conditioning trial; mice were treated with saline immediately prior to placement in the box. Finally, a 30-min "drug-present" preference test was performed 2 days after the drug-free preference test (after a weekend break); mice were treated with MA immediately prior to placement in the box. Mice were tested at an average age of $91 \pm 1$ days, with a range of 73-107 days; mice were tested between 1000 and $1400 \mathrm{~h}$.

\section{Experiment 3: MA-Induced Conditioned Taste Aversion Testing in MAHDR-Taar1 ${ }^{+/+}$ $\mathrm{KI}$ and MAHDR-Taar1m1J/m1J Control Mice}

Male and female MAHDR-Taar1 ${ }^{+/+}$KI and MAHDRTaar $1^{m 1 J / m 1 J}$ control mice were tested for sensitivity to conditioned taste aversion induced by $2 \mathrm{mg} / \mathrm{kg} \mathrm{MA}$, a dose that has produced consistent differences in mice with different Taar1 genotypes $(22,27)$. This study was conducted at the VAPORHCS using our established procedures. A novel $0.2 \mathrm{M} \mathrm{NaCl}$ solution was offered as the conditioned cue just prior to MA treatment to create an association with the interoceptive effects of MA. Briefly, mice were weighed, singly-housed, and familiarized to drinking water from a $10-\mathrm{ml}$ graduated cylinder fitted with a sipper tube (study days -1 and 0 ). Water access was then limited to $2 \mathrm{~h}$ per day for a 4-day acclimation period to induce motivation to drink the novel $\mathrm{NaCl}$ solution at a particular time of each day (study days 1-4). Beginning on day 5 , the $\mathrm{NaCl}$ solution was offered for $1 \mathrm{~h}$ every other day for 6 presentations (days $5,7,9,11,13$, and 15). No treatment was given after the first presentation, which was a trial intended to reduce neophobia. On the remaining $\mathrm{NaCl}$ access days, with the exception of the last, saline or MA was injected immediately after the drinking period. $\mathrm{NaCl}$ consumption was measured in $\mathrm{ml}$. To ensure proper hydration, $3 \mathrm{~h}$ post-injection, mice were given access to water for $30 \mathrm{~min}$, and they had $2 \mathrm{~h}$ water access on days between trials. Mice were tested at an average age of $93 \pm 1$ days, with a range of 82-112 days; $\mathrm{NaCl}$ access occurred at 0900-1000 h.

\section{Experiments 4 and 5: Two-Bottle Choice Methamphetamine Intake in DBA/2J-Taar1 $1^{+/+} \mathrm{KI}$ and DBA/2J-Taar1 ${ }^{m 1 \mathrm{~J} / \mathrm{m} 1 \mathrm{~J}}$ Control, and in C57BL/6J-Taar1 ${ }^{m 1 \mathrm{~J} / \mathrm{m} 1 \mathrm{~J}} \mathrm{KI}$ and C57BL/6J-Taar1 ${ }^{+/+}$Control Mice}

A two-bottle choice MA vs. water drinking procedure, similar to that used to characterize voluntary MA intake in our previous studies was used (15-18). This study was conducted at JAX. One day prior to testing, male and female mice were singly housed and offered two water-filled $50 \mathrm{ml}$ polypropylene centrifuge tubes (item number 430291; Corning, Corning, NY) fitted with rubber stoppers (Fisher Scientific, Pittsburgh, PA, USA) and single ballbearing stainless steel sipper tubes (Sta Pure Systems, Carnegie, PA, USA) to provide experience with consuming fluid from these tubes. On test days 2-5, mice were offered one water tube and a tube containing a $10 \mathrm{mg} / \mathrm{L}$ solution of $\mathrm{MA}$ in water. On days 6-17, the tubes contained water vs. $20 \mathrm{mg} / \mathrm{L}$, then $40 \mathrm{mg} / \mathrm{L}$, and then $80 \mathrm{mg} / \mathrm{L} \mathrm{MA}$, with each MA concentration offered for 4 consecutive days. During the MA phase, mice had access to MA $24 \mathrm{~h}$ /day and tubes were weighed prior to cage placement and again every $48 \mathrm{~h}$. Changes in MA concentration were accompanied by fresh tubes and switching of the position of the water vs. MA tube to account for potential side bias in fluid intake. Mice were weighed on days 1 and 17 of the study, and weights on those days were averaged to approximate $\mathrm{mg} / \mathrm{kg}$ MA consumed. Two separate studies were conducted. The first included DBA/2J-Taar $1^{+/+} \mathrm{KI}$ and DBA/2J-Taar $1^{\mathrm{m} 1 \mathrm{~J} / \mathrm{m} 1 \mathrm{~J}}$ control mice, tested at an average age of $72 \pm 2$ days, with a range of 56-88 days. The other included C57BL/6J-Taar $1^{\mathrm{m1J} / \mathrm{ml} J} \mathrm{KI}$ and C57BL/6J-Taar1 $1^{+/+}$control mice, tested at an average age of 75 \pm 1 days, with a range of 55-88 days.

\section{Experiments 6 and 7: MA-Induced Body Temperature Changes in DBA/2J-Taar1 ${ }^{+/+}$ and DBA/2J-Taar1 $1 \mathrm{~m} / \mathrm{J} / \mathrm{m} 1 \mathrm{~J}$ Control, and in C57BL/6J-Taar1 $1 \mathrm{~m} / \mathrm{m} 1 \mathrm{~J} \mathrm{KI}$ and C57BL/6J-Taar1+/+ Control Mice}

Male and female mice were tested for the effect of $2 \mathrm{mg} / \mathrm{kg}$ MA on core body temperature using our established procedures. This MA dose consistently produces hypothermia in MALDR mice and other mice that possess $\operatorname{Taarl}^{+}$, a response that is absent in MAHDR mice and other mice that lack TAAR1 function $(20,22)$. This study was conducted at the VAPORHCS using our established procedures. Mice were moved to the procedure room at $0800-0830 \mathrm{~h}$, weighed, isolated in acrylic plastic cubicles to prevent huddling-associated body temperature changes, and left undisturbed for $1 \mathrm{~h}$ to acclimate to the testing environment, maintained at a temperature of $21 \pm$ $1^{\circ} \mathrm{C}$. A baseline temperature was then obtained at $0900-0930 \mathrm{~h}$, designated as time 0 (T0), using a $5 \mathrm{~mm}$ glycerin-coated rectal probe attached to a Thermalert $\mathrm{TH}-8$ digital thermometer (Sensortek, Clifton, New Jersey). Mice were then immediately treated with saline or $2 \mathrm{mg} / \mathrm{kg}$ MA and returned to their holding cubicles. Temperatures were subsequently obtained at T30, T60, T90, T120, T150, and T180 min post-injection. Experiment 6 included DBA/2J-Taar $1^{+/+} \mathrm{KI}$ and DBA/2J-Taar $1^{\mathrm{m} 1 \mathrm{~J} / \mathrm{m} 1 \mathrm{~J}}$ control mice, tested at an average age of $92 \pm 1$ days, with a range of $62-$ 122 days. Experiment 7 included C57BL/6J-Taar $1^{m 1 / / m 1 J} \mathrm{KI}$ and C57BL/6J-Taar1 $1^{+/+}$control mice, tested at an average age of 82 \pm 1 days, with a range of 62-108 days.

\section{Experiment 8: Morphine-Induced Body Temperature Changes in MAHDR-Taar1 ${ }^{+/+}$ $\mathrm{KI}$ and MAHDR-Taar1 ${ }^{m 1 \mathrm{~J} / m 1 \mathrm{~J}}$ Control Mice}

Male and female MAHDR-Taar1 ${ }^{+/+}$KI and MAHDRTaar $1^{m 1 J / m 1 J}$ control mice were tested for sensitivity to the hypothermic effect of 15 and $30 \mathrm{mg} / \mathrm{kg}$ morphine. These doses 
were chosen from our previous research in the MADR lines (25). This study was conducted at the VAPORHCS, and experimental details were identical to those described for experiments 6 and 7 . Mice were tested at an average age of $85 \pm 1$ days, with a range of 65-109 days.

\section{Statistics}

Data were analyzed using factorial ANOVA with repeated measures as appropriate. Independent grouping factors are described with the results for each study. Complex interactions involving more than 2 factors were first examined by 2-way ANOVA at each level of the third factor. Significant 2-way interactions were examined for simple main effects and means were compared using the Newman-Keuls post-hoc test. The number of post-hoc comparisons was reduced by assessing changes from one mean to the next for concentration, time, and trial effects, or between first and subsequent trials.

\section{RESULTS}

\section{Baseline Data}

Baseline body weight data collected across studies, along with age ranges, are summarized in Table 1. Although there were some significant differences between genotypes in baseline body weight, differences were not consistently found across studies, suggesting that they were specific to the particular groups of animals included in a given experiment. Thus, C57BL/6J$\operatorname{Taar1}^{\mathrm{m1J} / \mathrm{mlJ}} \mathrm{KI}$ and C57BL/6J-Taar1 $1^{+/+}$control mice had equivalent body weights in both studies in which they were tested; DBA/2J-Taar $1^{+/+} \mathrm{KI}$ and DBA/2J-Taar $1^{m 1 J / m 1 J}$ control mice differed in body weight in one, but not the other experiment; and MAHDR-Taar1 ${ }^{+/+}$KI and MAHDR-Taar1 $1^{m 1 / m 1 J}$ control mice had comparable body weights in two studies and differed in the remaining two. When significant, mean differences ranged from 1.1 to $2.2 \mathrm{~g}$. Total volume of water consumed was recorded prior to tastant access in Experiment 1 and there was no significant difference between the genotypes (mean $\pm \mathrm{SEM}=$ $5.8 \pm 0.2 \mathrm{ml}$ vs. $6.0 \pm 0.2 \mathrm{ml}$ for KI and Control, respectively). Other measures, including total volume of fluid consumed, baseline locomotor activity level, and baseline body temperature are reported with the experiments during which these data were collected.

\section{Experiment 1: Novel Tastant Intake and Preference in MAHDR-Taar1 ${ }^{+/+} \mathrm{KI}$ and MAHDR-Taar1 ${ }^{m 1 J} / m^{1 J}$ Control Mice}

Data for each tastant were analyzed separately by repeated measures factorial ANOVA grouped on mouse line and sex, with concentration as the repeated measure.

\section{SACC Intake, Preference, and Total Volume Consumed \\ MAHDR-Taar $1^{+/+}$KI and MAHDR-Taar $1^{m 1 J / m 1 J}$ control mice did not differ in SACC intake or preference (calculated as $\mathrm{ml}$ from tastant tube/total $\mathrm{ml}$ consumed). The initial analysis of SACC intake data (Figure 1A) identified significant effects of sex $\left[F_{(1,44)}\right.$ $=4.7, p=0.036]$ and SACC concentration $\left[F_{(1,44)}=124.2, p<\right.$}

0.0001]. Female mice consumed more SACC than males (mean $\pm \mathrm{SEM}=106.6 \pm 10.4 \mathrm{mg} / \mathrm{kg}$ vs. $77.9 \pm 6.6 \mathrm{mg} / \mathrm{kg}$, respectively), and mice consumed more SACC when it was offered at the higher concentration. These outcomes were not dependent on mouse line. For SACC preference (Figure 1B) and total volume consumed from the water plus SACC tubes (Figure 1C), there were no significant effects of line, sex, or concentration.

\section{QUIN Intake, Preference, and Total Volume Consumed}

MAHDR-Taar1 ${ }^{+/}$KI mice consumed more QUIN and had a higher QUIN preference ratio, compared to MAHDRTaar1 $1^{m 1 J / m 1 J}$ control mice. The initial analysis of QUIN intake data (Figure 1D) identified a significant line $\mathrm{x}$ QUIN concentration interaction $\left[F_{(1,44)}=13.9, p=0.0005\right]$. There were no effects of sex. Follow-up analyses indicated that more QUIN was consumed by mice of both lines when the concentration was increased. The lines consumed comparable amounts of QUIN at the lower concentration, but MAHDR-Taar1 ${ }^{+/+} \mathrm{KI}$ mice consumed more QUIN than MAHDR-Taar $1^{\mathrm{m} 1 \mathrm{~J} / \mathrm{ml} J}$ control mice when the QUIN concentration was increased $(p=0.001)$. For QUIN preference (Figure 1E), there was a significant main effect of line $\left[F_{(1,44)}=6.2, p=0.02\right]$, with MAHDR-Taar ${ }^{+/+} \mathrm{KI}$ mice exhibiting higher preference than MAHDR-Taar $1^{m 1 J / m 1 J}$ control mice. For total volume consumed (Figure 1F), there was a significant line $\mathrm{x}$ concentration interaction $\left[F_{(1,44)}=11.6, p=\right.$ 0.001 ] that was associated with smaller volumes consumed by MAHDR-Taar1 ${ }^{+/+}$KI mice when the lower vs. higher QUIN concentration was offered ( $p<0.0001 ; 4.9 \pm 0.2$ vs. $5.8 \pm 0.2$ for the 0.015 and $0.03 \mathrm{mM}$ concentrations, respectively). However, there were no significant differences between the lines in total volume consumed at either concentration.

\section{Experiment 2: MA-Induced Conditioned Place Preference Testing in MAHDR-Taar1 ${ }^{+/+} \mathrm{KI}$ and MAHDR-Taar1 ${ }^{m 1 J} / \mathrm{m}^{1 J}$ Control Mice}

Data analyses considered percent time spent on the drug-paired floor during the pre-test, drug-free test and drug-present test, as measures of initial floor type bias, preference for floor cues induced by prior association with MA, and preference for MAassociated floor cues when tested during the associative state (Figure 2A). Locomotor activity data collected during these tests were also analyzed (Figure 2B). Data were analyzed by repeated measures factorial ANOVA grouped on mouse line and sex, with test day as the repeated measure.

\section{Place Preference}

Floor cues were initially equally preferred, and MA induced a conditioned preference in MAHDR-Taar1 $1^{m 1 J / m 1 J}$ control mice, but not MAHDR-Taar1 ${ }^{+/+}$KI mice. There was a significant line $\times$ test day interaction $\left[F_{(2,184)}=3.54, p=0.03\right]$, but no significant effects of sex. For initial preference, there was no significant difference between the lines for percent time spent on the assigned drug-paired floor, and values were near $50 \%$, indicating that the floor types were approximately equally preferred before conditioning. For the drug-free preference test, 
TABLE 1 | Body weight and age range data for each study.

\begin{tabular}{|c|c|c|c|c|c|c|}
\hline \multirow[b]{2}{*}{ Exp number } & \multirow[b]{2}{*}{ Study description } & \multirow[b]{2}{*}{ Mouse model } & \multirow[b]{2}{*}{ Age range (days) } & \multicolumn{2}{|c|}{ Body weight (g \pm SEM) } & \multirow[b]{2}{*}{ Mouse line comparison } \\
\hline & & & & $\mathbf{K I}$ & Control & \\
\hline (1) & Tastant intake & $\begin{array}{l}\text { MAHDR-Taar1+/+ KI } \\
\text { vs. Control }\end{array}$ & $77-87$ & $25.1 \pm 0.7$ & $25.7 \pm 0.7$ & $\mathrm{KI}=$ Control \\
\hline (2) & MA conditioned place preference & $\begin{array}{l}\text { MAHDR-Taar1+/+ KI } \\
\text { vs. Control }\end{array}$ & 73-107 & $25.7 \pm 0.4$ & $27.9 \pm 0.4^{\star \star \star}$ & $\mathrm{KI}<$ Control \\
\hline (3) & MA conditioned taste aversion & $\begin{array}{l}\text { MAHDR-Taar1+/+ KI } \\
\text { vs. Control }\end{array}$ & $82-112$ & $26.8 \pm 0.6$ & $27.9 \pm 0.6$ & $\mathrm{KI}=$ Control \\
\hline (4) & MA intake & $\begin{array}{l}\text { DBA/2J-Taar1+/+ KI } \\
\text { vs. Control }\end{array}$ & $56-88$ & $21.2 \pm 0.7$ & $20.5 \pm 0.7$ & $\mathrm{KI}=$ Control \\
\hline (5) & MA intake & $\begin{array}{l}\text { C57BL/6J-Taar1 } 1 \mathrm{m1J} / \mathrm{m} 1 \mathrm{~J} \mathrm{KI} \\
\text { vs. Control }\end{array}$ & $55-88$ & $23.0 \pm 0.5$ & $23.8 \pm 0.3$ & $\mathrm{KI}=$ Control \\
\hline (6) & MA body temperature & $\begin{array}{l}\text { DBA/2J-Taar1+/+ KI } \\
\text { vs. Control }\end{array}$ & $62-122$ & $25.2 \pm 0.4$ & $27.0 \pm 0.4^{\star \star}$ & $\mathrm{KI}<$ Control \\
\hline (7) & MA body temperature & $\begin{array}{l}\text { C57BL/6J-Taar1 } 1 \mathrm{m1} / \mathrm{J} 1 \mathrm{~J} \mathrm{KI} \\
\text { vs. Control }\end{array}$ & $62-108$ & $24.0 \pm 0.2$ & $23.9 \pm 0.2$ & $\mathrm{KI}=$ Control \\
\hline (8) & Morphine body temperature & $\begin{array}{l}\text { MAHDR-Taar1+/+ KI } \\
\text { vs. Control }\end{array}$ & 65-109 & $26.1 \pm 0.3$ & $27.1 \pm 0.3^{*}$ & $\mathrm{KI}<$ Control \\
\hline
\end{tabular}

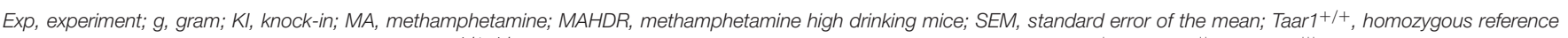

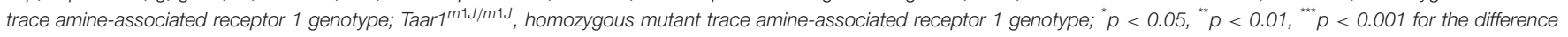
between mouse lines.

there was a significant difference between the lines $(p=0.02)$, with the MAHDR-Taar $1^{m 1 / m 1 J}$ controls spending more time on the drug-paired floor than the MAHDR-Taar $1^{+/+}$KI mice. A similar outcome was obtained for the drug-present preference test, with MAHDR-Taar $1^{\mathrm{m} 1 J / m 1 J}$ controls spending significantly more time on the drug-paired floor than the MAHDR-Taar $1^{+/+}$ KI mice $(p=0.007)$.

Evidence for MA-conditioned preference is indicated by a difference between percent time on the initial test day vs. the two post-conditioning preference test days. For MAHDRTaar $1^{m 1 / / m 1 J}$ control mice, there was a significant effect of test day $\left[F_{(2,94)}=21.4, p<0.0001\right]$, and post-hoc mean comparisons indicated that percent time was greater after MA conditioning when mice were tested under both drug-free and drug-present states $(p s<0.001)$. For MAHDR-Taar $1^{+/+} \mathrm{KI}$ mice, there was no significant effect of test day; thus, there was no evidence for MA-induced conditioned place preference in these mice.

\section{Locomotor Activity During Preference Testing}

There was a significant sex $\times$ test day interaction $\left[F_{(2,184)}=3.42\right.$, $p=0.03$. Activity levels were comparable for males and females during the initial and drug-free preference tests, but males were significantly more active than females during the drug-present test $(p=0.03 ; 3,753 \pm 119$ and $3,319 \pm 157$ for males and females, respectively). Sex differences were not dependent on line, but there was a significant line $\mathrm{x}$ test day interaction $\left[F_{(2,184)}=5.49, p=0.005\right]$. Activity levels were comparable between the two genotypes during the initial preference test. Both genotypes increased their activity during the subsequent 2 tests (all $p s<0.001$ ), with the highest level of locomotion during the drug-present test and greater activity in MAHDR-Taar $1^{+/+} \mathrm{KI}$, compared to MAHDR-Taar $1^{m 1 J / m 1 J}$ control mice $(p=0.02$ and 0.053 on the drug-free and drug-present test day, respectively).

\section{Locomotor Activity During Conditioning}

Locomotor activity level data during saline and MA conditioning trials were analyzed for sex, line, and conditioning trial effects. For saline trial data (Figure 3A), there were significant effects of sex $\left[F_{(1,92)}=7.75, p=0.007\right]$ and trial $\left[F_{(5,460)}=10.58\right.$, $p<0.0001]$. Males were more active than females and activity levels declined significantly from trial 1 to $2(p<0.001)$, and were then stable. For MA trial data (Figure 3B), there were no significant sex effects, but there was a significant line $\times$ trial interaction $\left[F_{(5,460)}=2.57, p=0.026\right]$. The mouse lines had comparable activity levels after the first MA treatment, then MAHDR-Taar1 ${ }^{+/+}$KI mice were more active than MAHDRTaar $1^{m 1 J / m 1 J}$ control mice on subsequent trials. Although there was a significant effect of trial within each line $(p s<0.001)$, significant sensitization to the locomotor stimulant effect of MA was found after fewer treatments in MAHDR-Taar1 ${ }^{+/+}$ KI mice.

\section{Experiment 3: MA-Induced Conditioned Taste Aversion Testing in MAHDR-Taar1//+ $\mathrm{KI}$ and MAHDR-Taar1m1J/m1J Control Mice}

MAHDR-Taar ${ }^{+/+}$KI mice, but not MAHDR-Taar1 ${ }^{\mathrm{mlJ} / \mathrm{mlJ}}$ control mice, exhibited sensitivity to MA-induced conditioned taste aversion (Figure 4). $\mathrm{NaCl}$ intake data were analyzed by repeated measures factorial ANOVA grouped on mouse line, sex, and treatment (saline or $2 \mathrm{mg} / \mathrm{kg} \mathrm{MA}$ ), with test trial as the repeated measure. There was a significant three-way interaction of line, treatment, and trial $\left[F_{(4,176)}=14.73, p\right.$ $<0.0001]$, but no significant effect of sex. For the MAHDRTaar $1^{m 1 J / m 1 J}$ control mice, there was a significant effect of trial $\left[F_{(4,88)}=4.76, p=0.002\right]$, but no effect of treatment; rather than a conditioned reduction in $\mathrm{NaCl}$ intake, these 


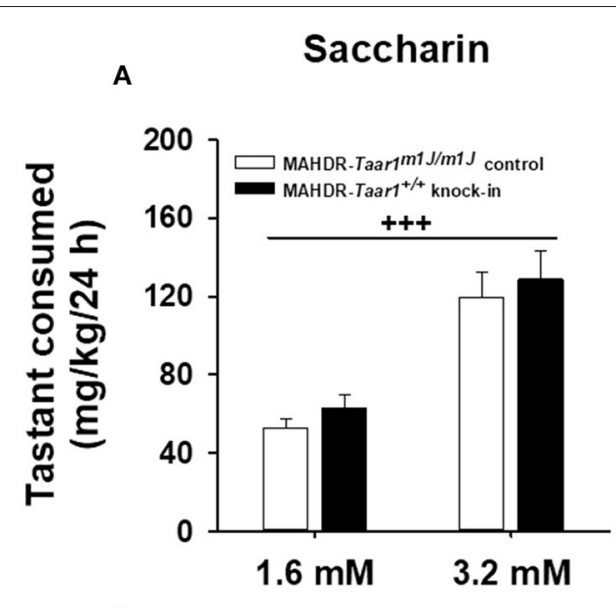

B

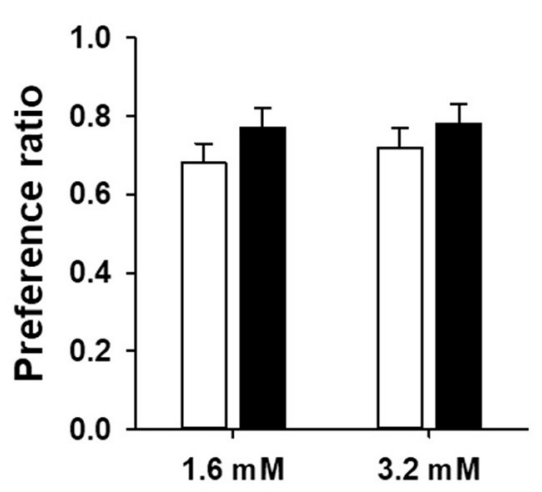

C

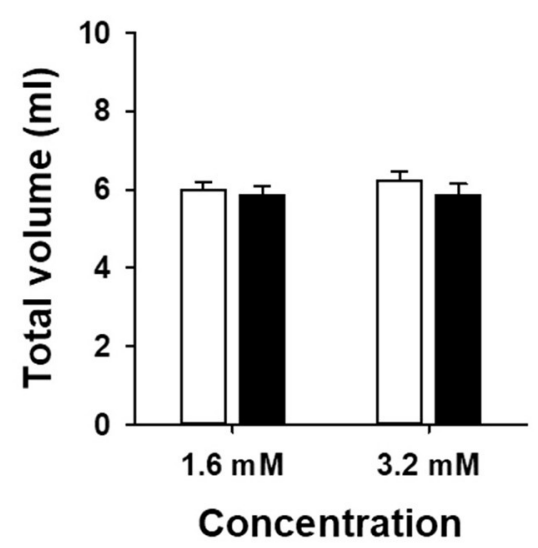

D

\section{Quinine}

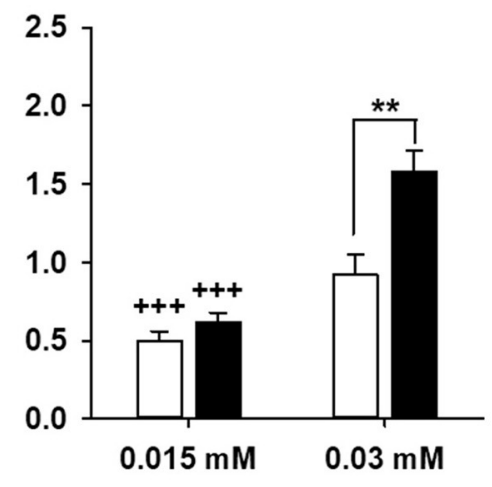

E

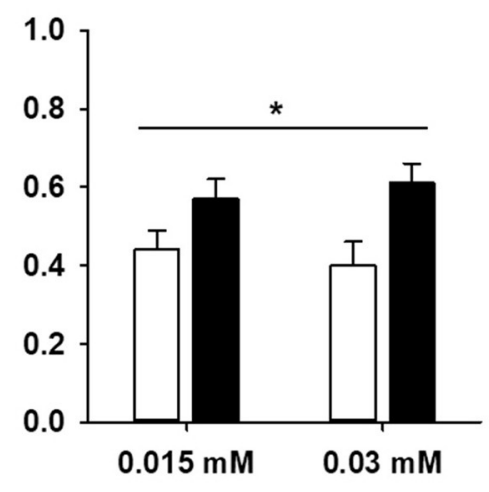

$\mathbf{F}$

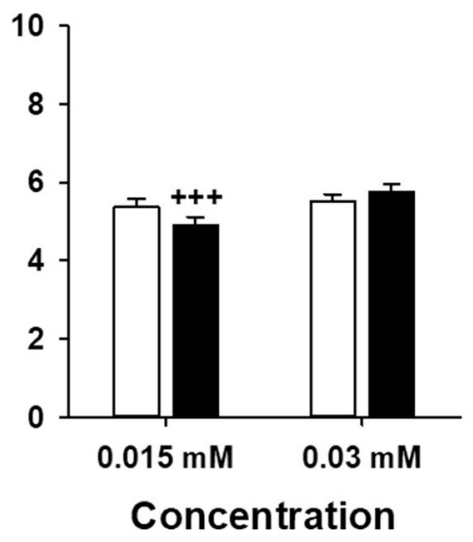

FIGURE 1 | Novel saccharin and quinine tastant intake and preference in MAHDR-Taar1+/+ KI and MAHDR-Taar1m1J/m1J control mice. Shown are means \pm SEM for (A) saccharin consumed ( $\mathrm{mg} / \mathrm{kg} / 24 \mathrm{~h})$, (B) saccharin preference ratio ( $\mathrm{ml}$ from saccharin tube/total $\mathrm{ml}$ consumed), (C) total volume (ml/24 h) consumed (water + saccharin solution) during access to each saccharin concentration, (D) quinine consumed (mg/kg $24 \mathrm{~h}$ ), (E) quinine preference ratio (ml from quinine tube/total ml consumed), and (F) total volume consumed (water + quinine solution) during quinine access. Tastants were offered vs. water for 4-day periods at increasing concentrations in counterbalanced order. Total $N=48$ mice $\left(12\right.$ mice per sex for the MAHDR-Taar $1^{+/+} \mathrm{Kl} ; 10$ female MAHDR-Taar $1^{m 1 J / m 1 J}$ control mice, and 14 male MAHDR-Taar $1^{m 1 J / m 1 J}$ control mice). ${ }^{\star} p<0.05,{ }^{* \star} p<0.01$ for the main effect of mouse line (E) or for the line difference at the indicated concentration (D);

${ }^{+++} p<0.001$ for the main effect of concentration (A) or for the concentration difference for the indicated mouse line (D,F). MAHDR, methamphetamine high drinking mice; Taar $1^{+/+}$, homozygous reference trace amine-associated receptor 1 genotype; Taar $1 \mathrm{~m} 1 \mathrm{~J} / \mathrm{m} 1 \mathrm{~J}$, homozygous mutant trace amine-associated receptor 1 genotype.

mice consumed significantly more $\mathrm{NaCl}$ during trials 35 , compared to trial $1(p=0.04,0.04$, and 0.0008 , for trials 3, 4, and 5, respectively; Figure 4A). For the MAHDRTaar $1^{+/+}$KI mice, there was a significant trial $\times$treatment interaction $\left[F_{(4,88)}=34.4, p<0.0001\right]$; there was no significant effect of trial for the saline treatment group, but there was for the MA treatment group $(p<0.0001)$. Post-hoc comparisons indicated that $\mathrm{NaCl}$ intake was lower for trials 2-5, 


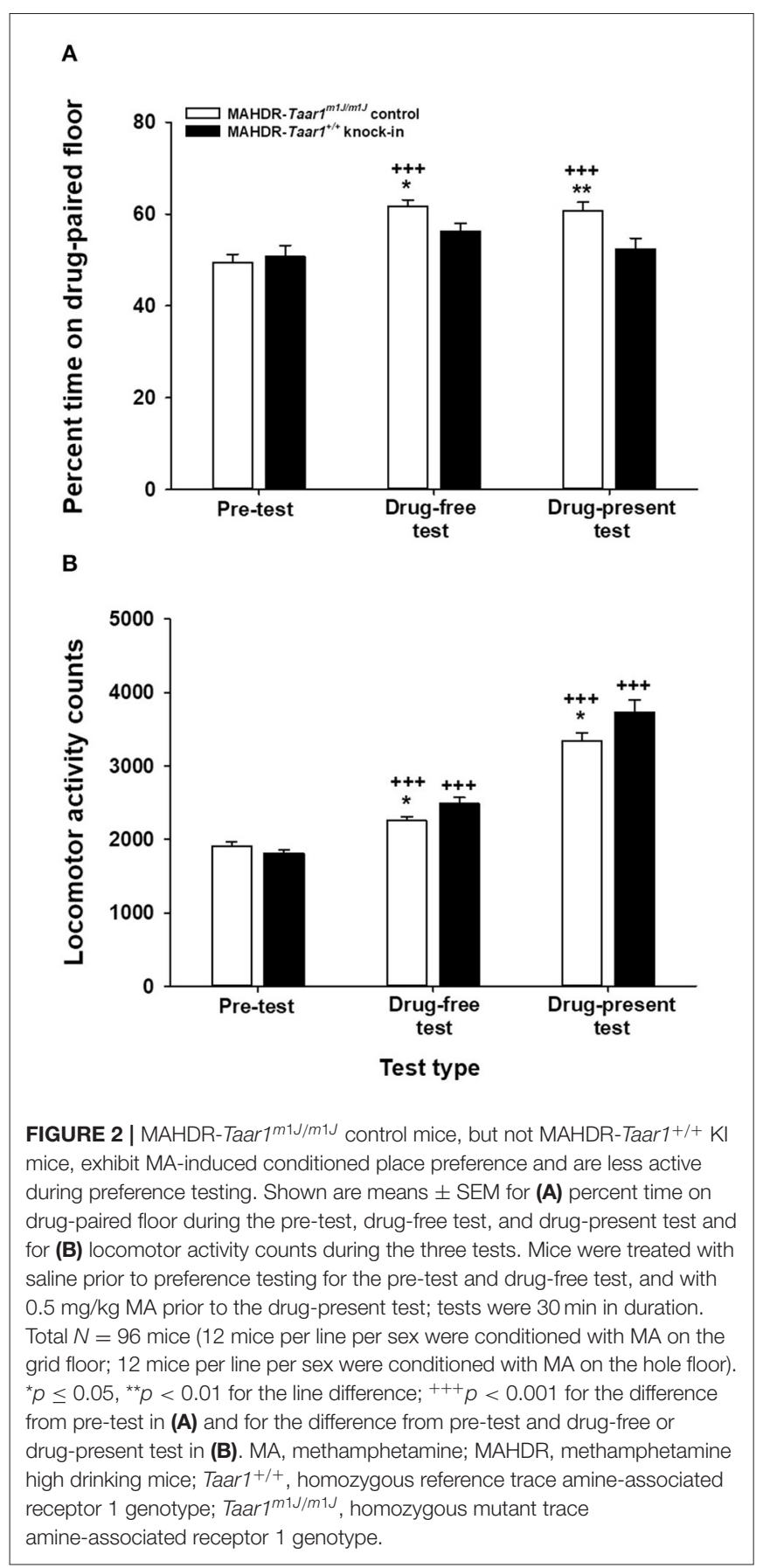

compared to trial 1 (all ps $<0.001$; Figure 4B), supporting the development of a conditioned taste aversion in MAHDRTaar $1^{+/+}$KI mice.

\section{Experiment 4: Two-Bottle Choice Methamphetamine Intake in DBA/2J-Taar1 ${ }^{+/+} \mathrm{KI}$ and DBA/2J-Taar1m1J/m1J Control Mice}

DBA/2J-Taar $1^{m 1 J / m 1 J}$ control mice consumed more MA and exhibited greater MA preference, compared to
DBA/2J-Taar $1^{+/+}$KI mice (Figure 5). Average MA intake, preference and total volume intake data were analyzed by repeated measures factorial ANOVA grouped on mouse line, sex, and MA concentration. For MA intake (Figure 5A), there was a significant line $\times$ MA concentration interaction $\left[F_{(3,78)}=5.9\right.$, $p=0.001]$, but no effect of sex. DBA/2J-Taar $1^{m 1 J / m 1 J}$ control mice consumed more MA than DBA/2J-Taar $1^{+/+}$KI mice at all MA concentrations. Intake significantly increased as MA concentration was increased for DBA/2J-Taar $1^{m 1 J / m 1 J}$ control mice $(p s<0.0001)$, with a statistical trend for KI mice $(p=0.06)$; results for mean comparisons are shown in Figure 5A.

For MA preference (Figure 5B), there was a main effect of line $\left[F_{(1,78)}=12.9, p=0.001\right]$, with DBA/2J-Taar $1^{m 1 J / m 1 J}$ control mice exhibiting a greater MA preference ratio, compared to DBA/2J-Taar $1^{+/+}$KI mice. There was also a significant main effect of concentration $\left[F_{(3,78)}=5.8, p=0.001\right]$; preference declined with increasing concentration. For total volume consumed (Figure 5C), the only significant effect was MA concentration $\left[F_{(3,84)}=7.7, p=0.0001\right]$; total volume increased with increasing MA concentration.

\section{Experiment 5: Two-Bottle Choice Methamphetamine Intake in C57BL/6J-Taar1 ${ }^{m 1 J / m 1 J} \mathrm{KI}$ and C57BL/6J-Taar1 ${ }^{+/+}$Control Mice}

C57BL/6J-Taar $1^{m 1 J / m 1 J}$ KI mice consumed more MA and exhibited greater MA preference than C57BL/6J-Taar1 ${ }^{+/+}$ control mice (Figure 6). MA intake, preference and total volume intake data were analyzed as described for Experiment 4. For MA intake (Figure 6A), there was a significant line $\mathrm{x}$ concentration interaction $\left[F_{(3,129)}=19.4, p<0.0001\right]$. C57BL/6J-Taar1 $1^{m 1 J / m 1 J}$ KI mice consumed more MA than C57BL/6J-Taar $1^{+/+}$control mice at all MA concentrations, except $10 \mathrm{mg} / \mathrm{L}$ (there was a strong statistical trend, $p=0.07)$. Although there was an increase in intake in both lines across concentration, the increase was steeper in the C57BL/6J-Taar $1^{m 1 J / m 1 J} \mathrm{KI}$ mice (see mean comparison results in Figure 6A). There was also a significant line $\mathrm{x}$ sex interaction $\left[F_{(1,129)}=5.4, p=0.025\right]$. However, this interaction was due to a magnitude effect, as there was a significant difference in MA intake between the KI and control mice $(p s<0.001)$ for both males and females $(5.2 \pm 0.6 \mathrm{mg} / \mathrm{kg}$ and $2.7 \pm 0.4$ for KI vs. control males; $7.5 \pm 0.6$ and $2.5 \pm 0.4$ for KI vs. control females), but the difference was 1.9 fold in males and 3 fold in females.

For MA preference (Figure 6B), there was a significant line $\times$ concentration interaction $\left[F_{(3,132)}=5.5, p=0.001\right]$, with significantly greater MA preference in C57BL/6J-Taar $1^{\mathrm{m} 1 \mathrm{~J} / \mathrm{m} 1 \mathrm{~J}}$ KI mice compared to C57BL/6J-Taar $1^{+/+}$control mice for the 40 and $80 \mathrm{mg} / \mathrm{L}$ concentrations $(p s<0.001)$. There was no significant effect of sex. MA preference decreased in the control mice across increasing concentrations $(p<0.0001$; see Figure 6B for mean comparisons), but remained stable in the KI mice. For total volume consumed (Figure 6C), there was a significant line $\times$ sex interaction $\left[F_{(1,44)}=13.9, p=\right.$ $0.0006]$, and a significant effect of concentration $\left[F_{(3,129)}=\right.$ $3.3, p=0.02]$. However, there were no significant increases in fluid consumption from one concentration to the next higher 


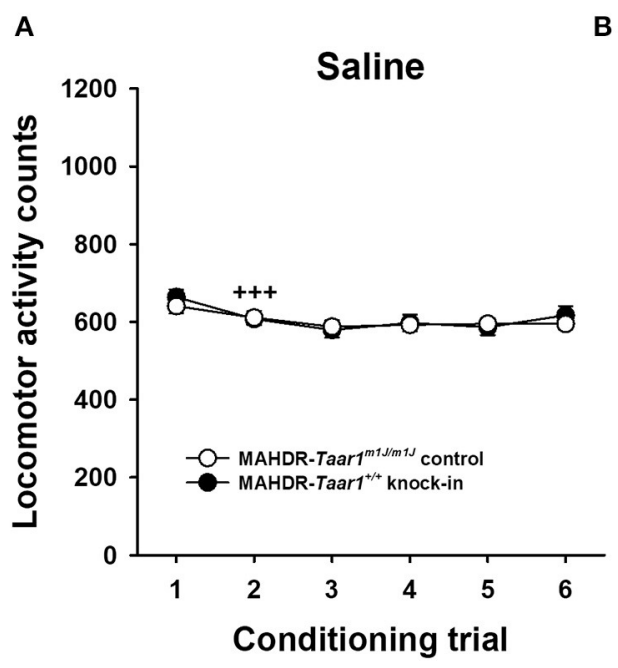

B

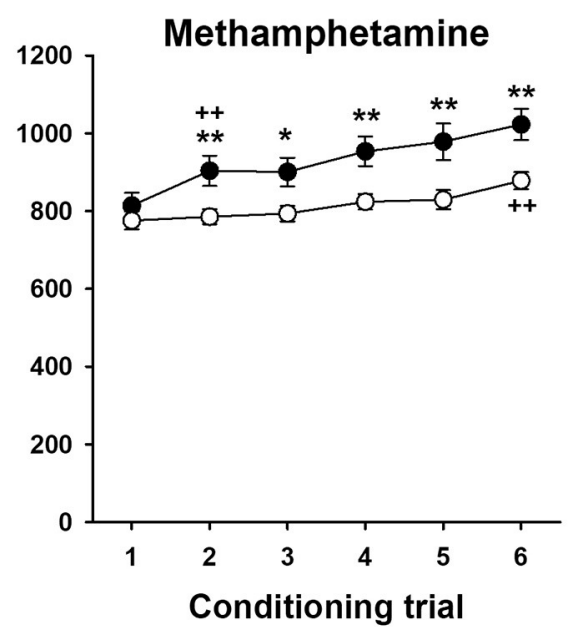

FIGURE 3 | Locomotor activity levels of saline-treated and acute MA-treated MAHDR-Taar ${ }^{+/+} \mathrm{KI}$ and MAHDR-Taar ${ }^{\mathrm{m} 1 \mathrm{~J} / \mathrm{m} 1 \mathrm{~J}}$ control mice are comparable, but locomotor sensitization is more rapid in MAHDR-Taar1 ${ }^{+/+}$KI mice. Shown are mean \pm SEM locomotor activity counts on each day of conditioning with either (A) saline or (B) MA. Mice were treated with saline or $0.5 \mathrm{mg} / \mathrm{kg} \mathrm{MA} \mathrm{immediately} \mathrm{prior} \mathrm{to} \mathrm{each} \mathrm{15-min} \mathrm{conditioning} \mathrm{trial.} \mathrm{Mice} \mathrm{were} \mathrm{the} \mathrm{same} \mathrm{animals} \mathrm{that} \mathrm{generated} \mathrm{the}$ data in Figure 2. ${ }^{*} p<0.05,{ }^{* *} p<0.01$ for the line difference; ${ }^{++} p<0.01,{ }^{+++} p<0.001$ for the difference from the previous conditioning trial. MA,

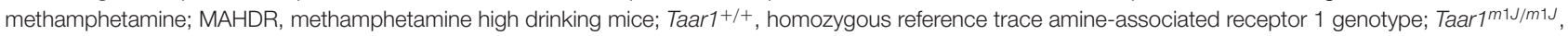
homozygous mutant trace amine-associated receptor 1 genotype.

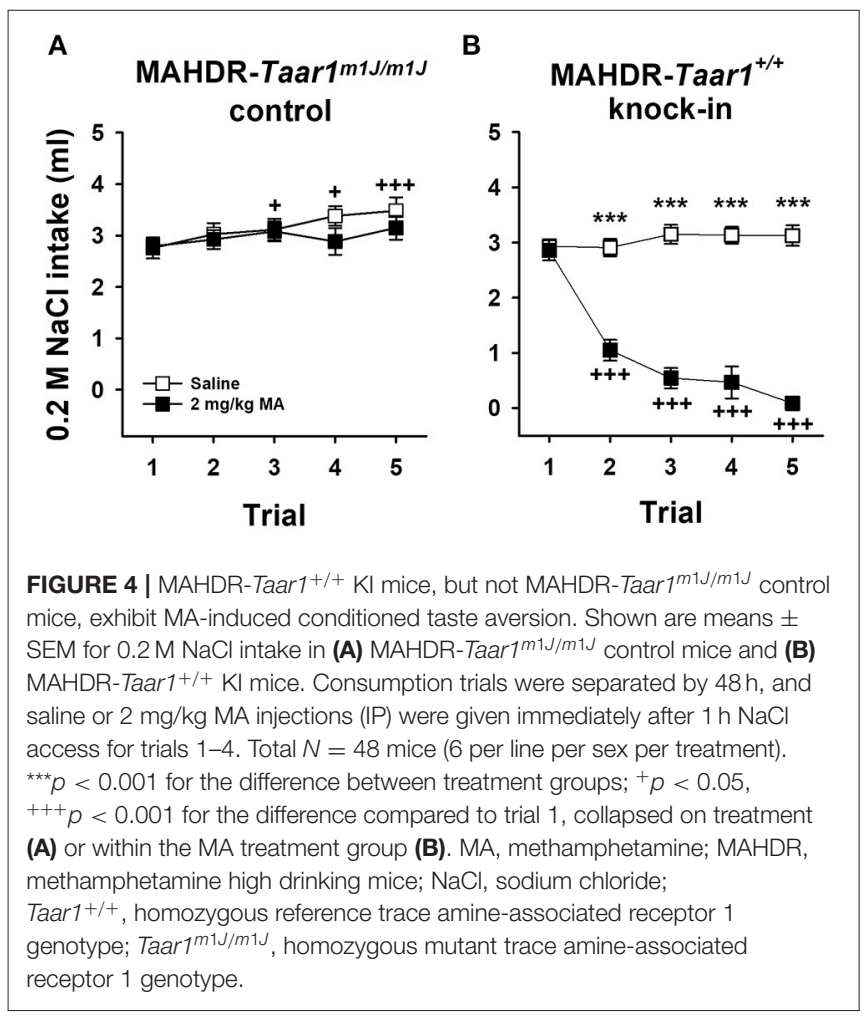

concentration. The line $\times$ sex interaction was due to significantly more total volume consumed by female C57BL/6J-Taar $1^{m 1 J / m 1 J}$ $\mathrm{KI}$ mice, compared to female C57BL/6J-Taar ${ }^{+/+}$control mice
$(27.6 \pm 1.2$ vs. $22.0 \pm 0.9$, respectively; $p=0.0004)$, but no significant difference between male mice of the KI and control lines ( $22.7 \pm 1.2$ vs. $24.7 \pm 0.8$, respectively; $p=0.17$ ).

\section{Experiment 6: MA-Induced Body Temperature Change in DBA/2J-Taar1 $1^{+/+}$ $\mathrm{KI}$ and DBA/2J-Taar1 ${ }^{m 1 \mathrm{~J} / \mathrm{m} 1 \mathrm{~J}}$ Control Mice}

DBA/2J-Taar $1^{+/+}$KI mice displayed MA-induced hypothermia, whereas DBA/2J-Taar $1^{m 1 J / m 1 J}$ control mice exhibited MAinduced hyperthermia (Figure 7). An interaction with sex was associated with a longer duration of the difference in body temperature response between the two lines in females than in males. Thus, the sex difference did not impact the conclusion regarding the impact of the genetic manipulation. The following analyses support our conclusions. Body temperature data were first analyzed by repeated measures factorial ANOVA grouped on line, sex and treatment (saline or $2 \mathrm{mg} / \mathrm{kg} \mathrm{MA}$ ), with time as the repeated measure. There was a significant fourway interaction $\left[F_{(5,365)}=4.3, p=0.0009\right]$. Because our main interest is in differences between the mouse lines in MA response, we performed ANOVAs to determine if there were effects of line, treatment and time within each sex. In both the males and females, there was a significant line $x$ treatment $\times$ time interaction $\left[F_{(5,180)}=6.4, p<0.0001\right.$ for males; $F_{(5,185)}=11.3, p<0.0001$ for females]. For both male and female DBA/2J-Taar ${ }^{m 1 J / m 1 J}$ control mice, there was a treatment $\times$ time interaction $\left[F_{(5,90)}=7.1, p<0.0001\right.$ for males; $F_{(5,95)}=9.2, p<0.0001$ for females]. Mean differences are indicated in Figures 7A,B. There were no differences in body temperature between the treatment groups at T0. Female DBA/2J-Taar $1^{m 1 J / m 1 J}$ control mice treated with MA had 


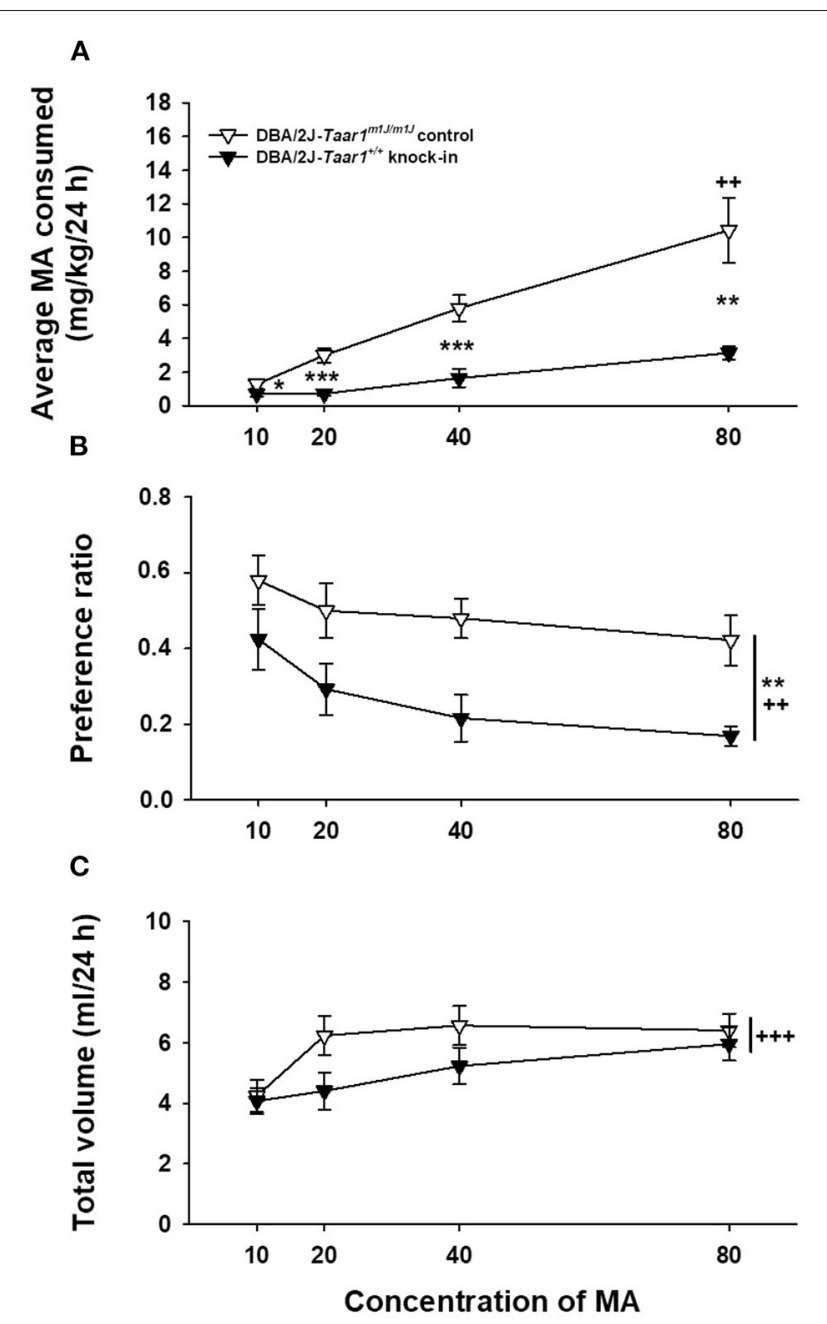

FIGURE 5 | DBA/2J-Taar1 ${ }^{m 1} \mathrm{~J} / m 1 \mathrm{~J}$ control mice consume more MA and exhibit greater MA preference, compared to DBA/2J-Taar1+/+ KI mice. Shown are means \pm SEM for (A) average MA consumed ( $\mathrm{mg} / \mathrm{kg} / 24 \mathrm{~h})$, (B) preference ratio ( $\mathrm{ml}$ from MA tube/total $\mathrm{ml}$ consumed), and $\mathbf{( C )}$ total volume consumed $(\mathrm{ml} / 24 \mathrm{~h})$ during two-bottle choice of water and ascending concentrations of MA. Each concentration was offered for a 4-day period. Total $N=32$ mice (eight per mouse line per sex); ${ }^{*} p<0.05$, ${ }^{* \star} p<0.01$, ${ }^{\star \star \star} p<0.001$ for the difference between mouse lines for a given concentration (A) or collapsed on concentration (B); ${ }^{++} p<0.01,{ }^{+++} p<0.001$ for the effect of concentration compared to the previous concentration $(\mathbf{A})$ or for the main effect of concentration (B,C). MA, methamphetamine; Taar1+/+, homozygous reference trace amine-associated receptor 1 genotype; Taar $1^{m 1} \mathrm{~J} / \mathrm{m} 1 \mathrm{~J}$, homozygous mutant trace amine-associated receptor 1 genotype. significantly higher body temperatures at T30-T180 than their saline-treated counterparts. A similar difference was found in males, beginning at T60. For both male and female DBA/2JTaar $1^{+/+}$KI mice, there was a treatment $\times$time interaction $\left[F_{(5,90)}=18.9, p<0.0001\right.$ for males; $F_{(5,90)}=8.8, p<0.0001$ for females]. Mean differences are indicated in Figures 7C,D. There were no differences in body temperature between the treatment groups at T0. Female DBA/2J-Taar $1^{+/+}$KI mice exhibited longlasting hypothermia from T30-T120, whereas males exhibited

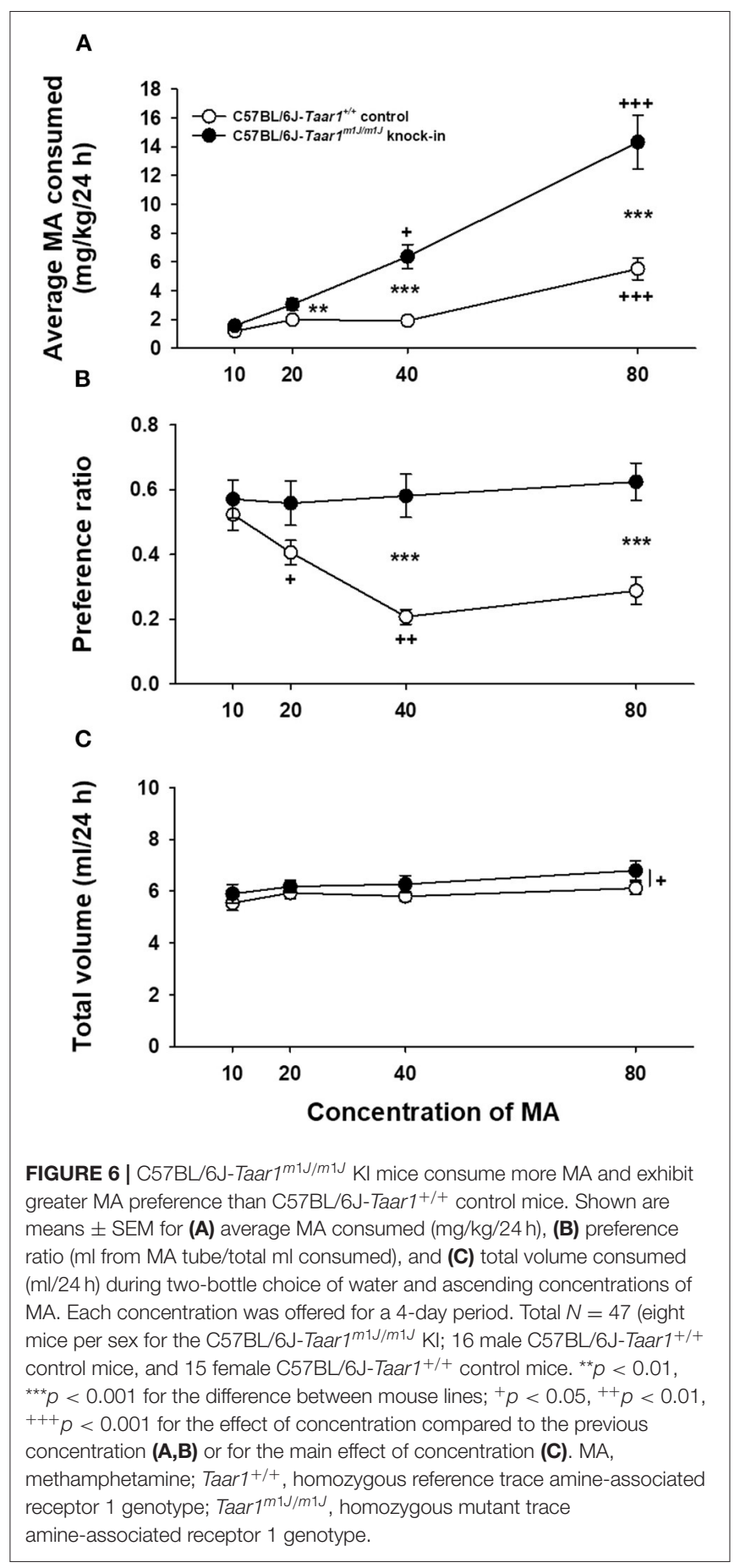

significant MA-induced hypothermia only at T30. The MAtreated males had significantly higher body temperatures than saline-treated males at T120 and T180.

We next examined the data for line, sex and time differences within each treatment condition. Data are presented in Supplementary Figure 1. For the saline-treated mice, there was a significant effect of time $\left[F_{(5,185)}=18.9, p<0.0001\right]$, but no significant effect of line or sex. Body temperature changes 


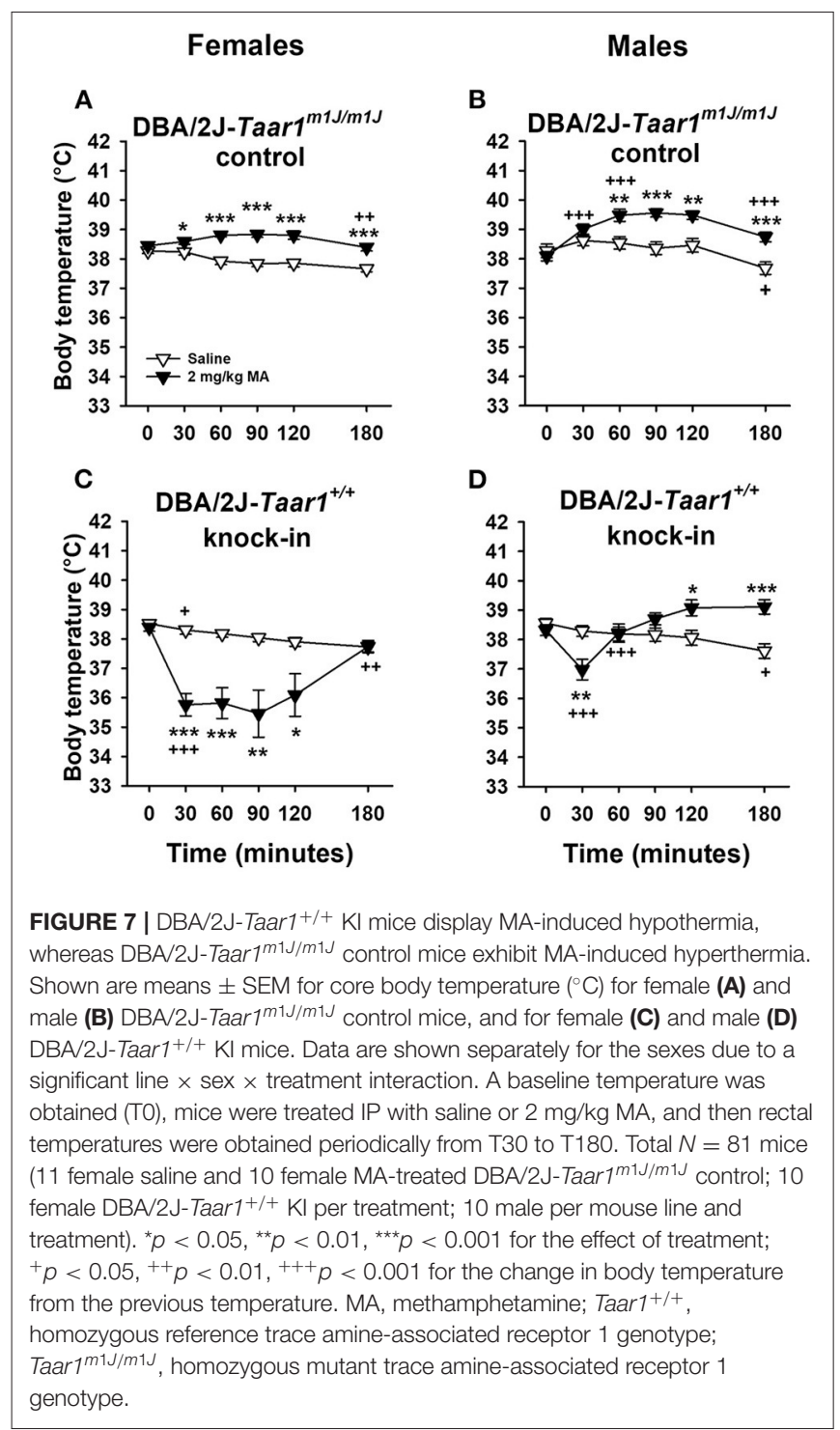

were examined by comparing adjacent means (i.e., change from the prior time point). Body temperature at T180 was significantly lower than at T120 $(p<0.0001)$. For the MAtreated mice, there was a significant 3-way interaction of line, sex and time $\left[F_{(5,180)}=3.8, p=0.003\right)$. There were no differences in body temperature between the lines for the MA-treatment group at T0. Female DBA/2J-Taar1 ${ }^{+/+}$KI mice had lower body temperatures than female DBA/2J-Taar $1^{\mathrm{m} 1 \mathrm{~J} / \mathrm{m} 1 \mathrm{~J}}$ control mice after MA treatment at T30-T180. A similar difference was found in males at T30-T90. Significant changes across time are indicated in Supplementary Figure 1.

\section{Experiment 7: MA-Induced Body Temperature Change in C57BL/6J-Taar1 ${ }^{m 1 \mathrm{~J} / \mathrm{m} 1 \mathrm{~J}} \mathrm{KI}$ and C57BL/6J-Taar1+/+ Control Mice}

C57BL/6J-Taar $1^{m 1 J / m 1 J}$ KI mice displayed MA-induced hyperthermia, whereas $\mathrm{C} 57 \mathrm{BL} / 6 \mathrm{~J}-$Taar$^{+/+}$control mice

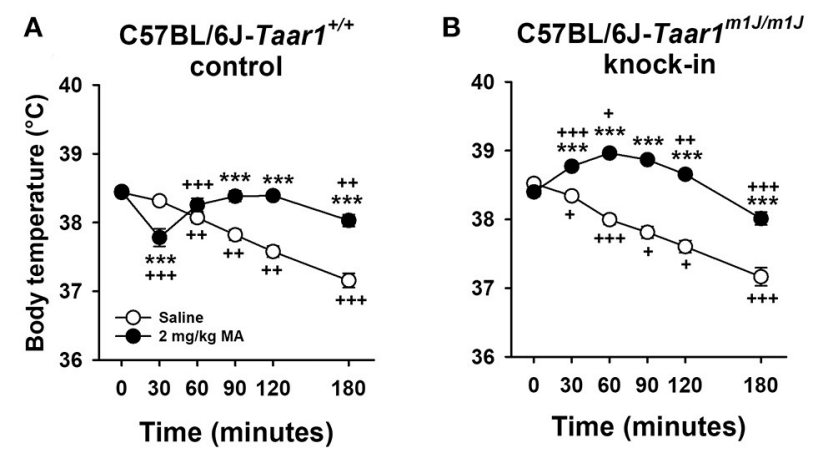

FIGURE 8 | C57BL/6J-Taar1 ${ }^{m 1} 1 \mathrm{~J} / \mathrm{m} 1 \mathrm{~J} \mathrm{KI}$ mice display MA-induced hyperthermia, whereas C57BL/6J-Taar1 ${ }^{+/+}$control mice exhibit MA-induced hypothermia. Shown are means \pm SEM for core body temperature $\left({ }^{\circ} \mathrm{C}\right)$ for (A) C57BL/6J-Taar1 ${ }^{+/+}$control and (B) C57BL/6J-Taar1 ${ }^{\text {m1J/m1J } \mathrm{KI} \text { mice. }}$ A baseline temperature was obtained (TO), mice were treated IP with saline or $2 \mathrm{mg} / \mathrm{kg} \mathrm{MA}$, and then rectal temperatures were obtained periodically from T30 to T180. Total $N=98$ ( 11 female and 13 male saline-treated C57BL/6J-Taar1 ${ }^{+/+}$control; 11 female and 12 male MA-treated C57BL/6J-Taar1 1+/+ control; 13 saline-treated C57BL/6J-Taar1m1J/m1J KI per sex; 12 female and 13 male MA-treated C57BL/6J-Taar1 ${ }^{m 1} \mathrm{~J} / \mathrm{m} 1 \mathrm{~J} \mathrm{KI}$ ). ${ }^{\star \star \star} p<0.001$ for the effect of treatment; ${ }^{+} p<0.05,{ }^{++} p<0.01$, ${ }^{+++} p<0.001$ for the change in body temperature from the previous temperature. MA, methamphetamine; Taar $1^{+/+}$, homozygous reference trace amine-associated receptor 1 genotype; $\operatorname{Taar} 1^{m 1} \mathrm{~J} / \mathrm{m} 1 \mathrm{~J}$, homozygous mutant trace amine-associated receptor 1 genotype.

exhibited MA-induced hypothermia (Figure 8). The following analyses support this summary. Body temperature data were first analyzed by repeated measures factorial ANOVA grouped on line, sex, and treatment (saline or $2 \mathrm{mg} / \mathrm{kg} \mathrm{MA}$ ), with time as the repeated measure. There were two significant three-way interactions; a line $\times$ treatment $\times$ time interaction $\left[F_{(5,450)}=\right.$ 20.0, $p<0.0001]$ and a sex $\times$ treatment $\times$ time interaction $\left[F_{(5,450)}=7.0, p<0.0001\right]$. There were no interactions of sex with line, indicating that line differences were not sex-dependent.

To examine the line $\times$ treatment $\times$ time interaction, data were examined for treatment effects within each line. For the C57BL/6J-Taar $1^{+/+}$control mice (Figure 8A), there was a significant treatment $\times$ time interaction $\left[F_{(5,225)}=34.7, p<\right.$ $0.0001]$. MA produced significant hypothermia at T30, and the declining temperatures that occurred in the saline group across time were reduced in the MA-treated mice; thus, they had higher body temperatures at T90-T180. For the C57BL/6J-Taar1 1 1J/m1J KI mice (Figure 8B), there was a significant treatment $\times$ time interaction $\left[F_{(5,245)}=37.2, p<0.0001\right]$. MA-treated mice had higher body temperatures than saline-treated mice at all time points except T0.

We next examined the data for line and time differences within each treatment condition. Data are presented in Supplementary Figure 2. For the saline group, there was a significant effect of time $\left[F_{(5,240)}=140.8, p<0.0001\right]$, but no body temperature differences between the mouse lines. For the MA treatment group, there was a significant line $\times$ time interaction $\left[F_{(5,230)}=23.0, p<0.0001\right]$, and the mouse lines differed in body temperature at all time points except 
T0 and T180. Significant changes across time are indicated in Supplementary Figure 2.

\section{Experiment 8: Morphine-Induced Body Temperature Changes in MAHDR-Taar1 ${ }^{+/+}$ $\mathrm{KI}$ and MAHDR-Taar1 ${ }^{\mathrm{m} 1 \mathrm{~J} / \mathrm{m} 1 \mathrm{~J}}$ Control Mice}

MAHDR-Taar $^{+/+}$KI and MAHDR-Taar $1^{m 1 J / m 1 J}$ control mice, exhibited comparable sensitivity to morphine-induced hypothermia (Figure 9). The following statistical outcomes support this conclusion. In the initial 4-way repeated measures ANOVA, the only significant effects involving line were line $\mathrm{x}$ morphine dose $\left[F_{(2,129)}=3.2, p=0.04\right]$ and line $\times$ time $\left[F_{(5,645)}\right.$ $=3.6, p=0.003$ ] interactions. However, further examination of the effect of line at each morphine dose, identified no statistically significant differences, and examination of the line $\times$ time interaction identified a significant line difference in body temperature only at T0 $(p<0.0001)$, with a higher temperature in MAHDR-Taar1 $1^{+/+}$KI than MAHDR-Taar1 $1^{m 1 / m 1 J}$ control mice of only $0.4^{\circ} \mathrm{C}$. Although line did not interact with morphine dose and time, data were analyzed separately for each line to demonstrate that morphine induced significant hypothermia. The outcomes of these analyses are represented in Figures 9A,B. Within each line, there was no effect of dose at T0, but there were significant dose effects at all other time points, supporting morphine-induced hypothermia.

In addition, there was a sex $\times$ treatment $\times$ time interaction $\left[F_{(10,645)}=2.2, p=0.02\right]$. When data were examined for sex differences, there was a significant sex $\times$ time interaction for the $0\left[F_{(5,220)}=2.6, p=0.03\right]$ and $30 \mathrm{mg} / \mathrm{kg}\left[F_{(5,225)}=\right.$ 3.8, $p=0.002$ ] dose groups, but not the $15 \mathrm{mg} / \mathrm{kg}$ dose group. Further examination of the effect of sex at each time point for the saline treatment dose, identified no statistically significant differences. For the $30 \mathrm{mg} / \mathrm{kg}$ dose group, females had lower temperatures than males at T30 $(p=0.004)$ and T60 $(p=0.03)$, reflecting greater morphine-induced hypothermia. The temperature difference was $1.2^{\circ} \mathrm{C}$ at $\mathrm{T} 30$ and $1.3^{\circ} \mathrm{C}$ at $\mathrm{T} 60$; however, this sex effect was not dependent on line and thus, did not impact conclusions regarding the genetic manipulation.

\section{DISCUSSION}

Our research provides new and conclusive evidence indicating that a Taar1 SNP with a key role in MA intake also impacts sensitivity to MA-induced conditioned place preference, conditioned taste aversion and hypothermia. Furthermore, we demonstrate impacts of Taar1 genotype on multiple genetic backgrounds and significant reciprocal effects of allele exchange by CRISPR-Cas9. Low MA intake is associated with low sensitivity to MA reward and high sensitivity to aversive effects of MA. Furthermore, we confirm prior evidence indicating that a gene in linkage disequilibrium with Taarl is responsible for a difference in sensitivity to morphine-induced hypothermia in the MADR mouse lines. Table 2 summarizes our key findings.
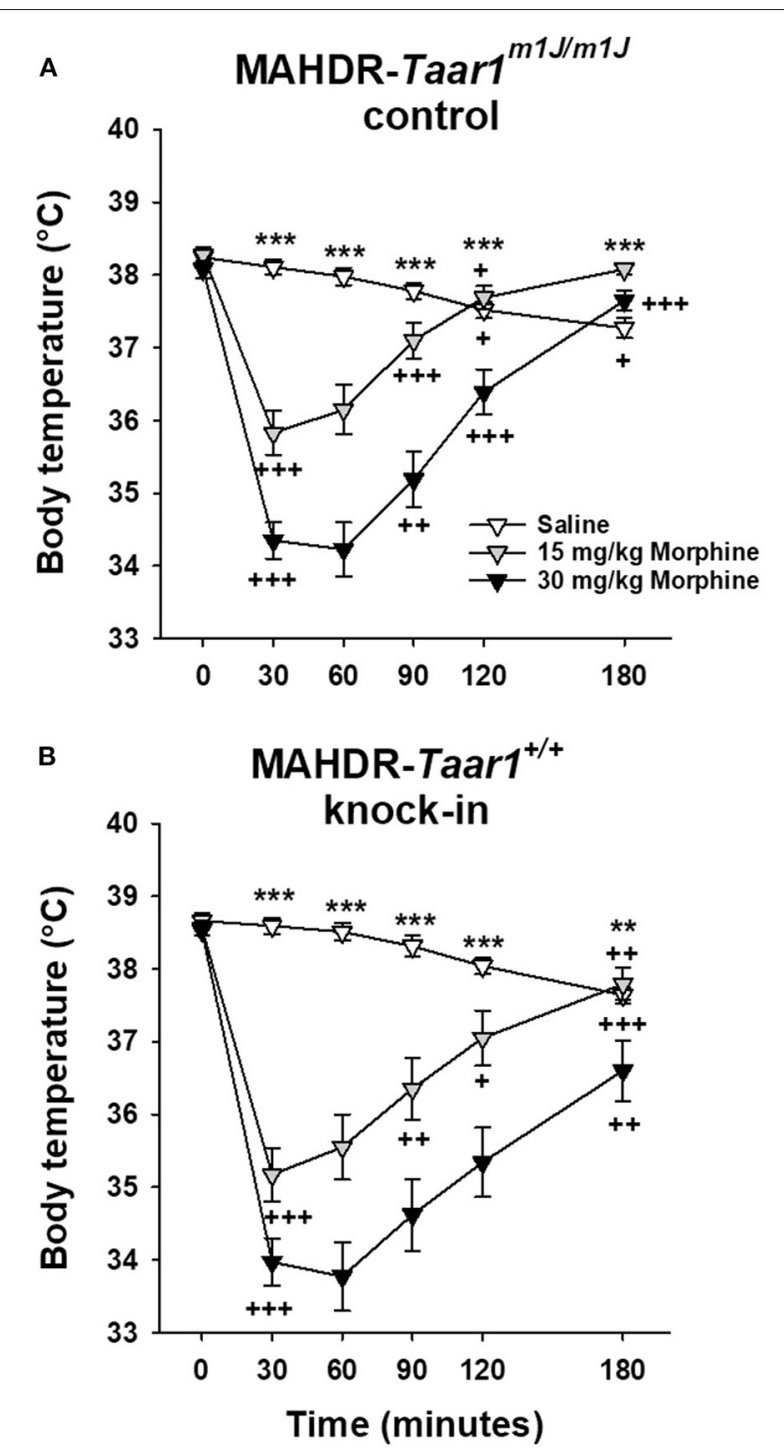

FIGURE 9 | MAHDR-Taar1 ${ }^{+/+} \mathrm{KI}$ and MAHDR-Taar1 ${ }^{m 1} \mathrm{~J} / \mathrm{m} 1 \mathrm{~J}$ control mice, exhibited comparable sensitivity to morphine-induced hypothermia. Shown are means \pm SEM for core body temperature $\left({ }^{\circ} \mathrm{C}\right)$ for $(\mathbf{A})$ MAHDR-Taar $1{ }^{\mathrm{m} 1 \mathrm{~J} / \mathrm{m} 1 \mathrm{~J}}$ control and (B) MAHDR-Taar1 ${ }^{+/+} \mathrm{KI}$ mice. A baseline temperature was obtained (TO), mice were treated IP with saline, 15 or $30 \mathrm{mg} / \mathrm{kg}$ morphine, and then rectal temperatures were obtained periodically from T30 to T180. Total $N=140$ mice (11 saline-treated MAHDR-Taar1 ${ }^{+/+} \mathrm{KI}$ per sex; 12, $15 \mathrm{mg} / \mathrm{kg}$ morphine-treated MAHDR-Taar1+/+ KI per sex; 11 male and 12 female 30 $\mathrm{mg} / \mathrm{kg}$ morphine-treated MAHDR-Taar $1+/+\mathrm{Kl} ; 12$ MAHDR-Taar1 ${ }^{m 1 \mathrm{~J} / \mathrm{m} 1 \mathrm{~J}}$ control mice per dose per sex). ${ }^{* *} p<0.01 ;{ }^{* \star *} p<0.001$ for the effect of treatment; ${ }^{+} p<0.05,{ }^{++} p<0.01,{ }^{+++} p<0.001$ for the change in body temperature from the previous temperature. MA, methamphetamine; MAHDR, methamphetamine high drinking mice; $\operatorname{Taar} 1^{+/+}$, homozygous reference trace amine-associated receptor 1 genotype; Taar $1^{m 1} \mathrm{~J} / \mathrm{m} 1 \mathrm{~J}$, homozygous mutant trace amine-associated receptor 1 genotype.

\section{Pleiotropic Effects of Taar1 on MA-Related Traits in MAHDR Mice}

MAHDR mice were selectively bred for high levels of voluntary MA intake using a two-bottle choice water vs. MA solution procedure. Subsequent investigation established that taste does 
TABLE 2 | Summary of results for Taar1 genotype effects for all experiments.

\begin{tabular}{|c|c|c|c|c|}
\hline Exp & Trait & Background & $\begin{array}{l}\text { Tastant or Drug, Dose } \\
\text { or Conc. }\end{array}$ & $\begin{array}{l}\text { Taar1 }^{+/+} \text {vs. } \\
\text { Taar }^{\text {m1J/m1J }}\end{array}$ \\
\hline \multirow[t]{3}{*}{ (1) } & Intake & MAHDR & SACC, 1.6 and $3.2 \mathrm{mM}$ & $=$ \\
\hline & Preference & MAHDR & SACC, 1.6 and $3.2 \mathrm{mM}$ & $=$ \\
\hline & Total volume & MAHDR & SACC, 1.6 and $3.2 \mathrm{mM}$ & $=$ \\
\hline \multirow[t]{3}{*}{ (1) } & Intake & MAHDR & QUIN, 0.015 and $0.03 \mathrm{mM}$ & $\geq$ \\
\hline & Preference & MAHDR & QUIN, 0.015 and $0.03 \mathrm{mM}$ & $>$ \\
\hline & Total volume & MAHDR & QUIN, 0.015 and $0.03 \mathrm{mM}$ & $=$ \\
\hline \multirow[t]{3}{*}{ (2) } & CPP baseline & MAHDR & Saline & $=$ \\
\hline & $\begin{array}{l}\text { CPP } \\
\text { drug-free }\end{array}$ & MAHDR & $\begin{array}{l}\text { MA, } 0.5 \mathrm{mg} / \mathrm{kg} \text { then saline } \\
\text { test }\end{array}$ & $<$ \\
\hline & $\begin{array}{l}\text { CPP drug- } \\
\text { present }\end{array}$ & MAHDR & $\begin{array}{l}\mathrm{MA}, 0.5 \mathrm{mg} / \mathrm{kg} \text { then } 0.5 \\
\mathrm{mg} / \mathrm{kg} \text { test }\end{array}$ & $<$ \\
\hline (3) & CTA & MAHDR & $\mathrm{MA}, 0$ and $2 \mathrm{mg} / \mathrm{kg}$ & $>$ \\
\hline \multirow[t]{3}{*}{ (4) } & Intake & DBA/2J & $\mathrm{MA}, 10-80 \mathrm{mg} / \mathrm{L}$ & $<$ \\
\hline & Preference & DBA/2J & $\mathrm{MA}, 10-80 \mathrm{mg} / \mathrm{L}$ & $<$ \\
\hline & Total volume & DBA/2J & MA, $10-80 \mathrm{mg} / \mathrm{L}$ & $=$ \\
\hline \multirow[t]{3}{*}{ (5) } & Intake & C57BL/6J & $\mathrm{MA}, 10-80 \mathrm{mg} / \mathrm{L}$ & $<$ \\
\hline & Preference & C57BL/6J & $\mathrm{MA}, 10-80 \mathrm{mg} / \mathrm{L}$ & $<$ \\
\hline & Total volume & C57BL/6J & $\mathrm{MA}, 10-80 \mathrm{mg} / \mathrm{L}$ & $<^{*}$ \\
\hline \multirow[t]{2}{*}{ (6) } & Hypothermia & DBA/2J & $\mathrm{MA}, 0$ and $2 \mathrm{mg} / \mathrm{kg}$ & $>$ \\
\hline & Hyperthermia & DBA/2J & $\mathrm{MA}, 0$ and $2 \mathrm{mg} / \mathrm{kg}$ & $<$ \\
\hline \multirow[t]{2}{*}{ (7) } & Hypothermia & C57BL/6J & $\mathrm{MA}, 0$ and $2 \mathrm{mg} / \mathrm{kg}$ & $>$ \\
\hline & Hyperthermia & C57BL/6J & $\mathrm{MA}, 0$ and $2 \mathrm{mg} / \mathrm{kg}$ & $<$ \\
\hline (8) & Hypothermia & MAHDR & $\begin{array}{l}\text { Morphine, 0, 15, and } \\
30 \mathrm{mg} / \mathrm{kg}\end{array}$ & $=$ \\
\hline
\end{tabular}

"This difference was found in females only; Conc., concentration; CPP, conditioned place preference; CTA, conditioned taste aversion; Exp, experiment; MA, methamphetamine; $M A H D R$, methamphetamine high drinking line; QUIN, quinine; SACC, saccharin; Taar $1^{+/+}$, homozygous reference trace amine-associated receptor 1 genotype;

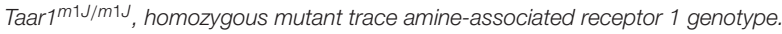

not provide an explanation for the difference in MA intake between the MADR lines $(16,18)$, the MAHDR mice will voluntarily consume binge-like levels of MA (17), and baseline measures, including locomotor activity, measures of learning and memory, body weight, and body temperature, do not systematically differentiate the lines (26). Furthermore, the lines do not differ in responses to cocaine or alcohol, but they do differ in responses to fentanyl, morphine and amphetamine-like drugs, including MDMA $(25,28-30)$. The current studies investigated whether the Taar1 SNP that impacts MA intake also plays a part in the reliable differences in MA-induced conditioned place preference, conditioned taste aversion and hypothermia we have observed between the MADR lines $(16,18,20,27)$. Our results confirm an impact of this polymorphism on all three traits.

MAHDR mice consume less morphine and exhibit greater morphine-induced hypothermia than MALDR mice $(25,28)$. Both Taar 1 and the $\mu$-opioid receptor gene, Oprm1, are on mouse chromosome $10,17 \mathrm{Mb}$ apart. We speculated that the differences in morphine consumption and hypothermia were associated with linkage disequilibrium and more likely an effect of different Oprm1 alleles inherited from the DBA/2J and C57BL/6J strains, known to impact morphine preference (31,
32). When we examined Taarl and Oprm1 genotype in MADR line mice tested for morphine-induced hypothermia, there was correspondence of magnitude of hypothermia with Oprm1, but not Taar1, genotype (25). The current data in the MAHDR KI model are consistent with the conclusion that the Taar1 SNP is not responsible for the difference in morphine-induced hypothermia between the MADR lines, and that another gene(s) is responsible. We have not tested the MAHDR KI mice for all of the traits previously examined in the MADR lines, but would not expect the KI and control lines to differ for cocaine or alcohol responses. We did observe an unexpected difference in quinine intake in experiment 1 , but it was the MA-avoiding line that consumed more quinine, so this result does not provide an explanation for higher consumption of bitter-tasting MA. Future studies will track the reliability of this outcome by repeating the study in all of the KI models.

Finally, the results for locomotor activity in the MAHDR KI and control mice agree with our prior findings in the MADR lines that also did not differ in acute locomotor response to 0.5 $\mathrm{mg} / \mathrm{kg}$ MA. However, the differences found here between the lines, with Taar $1^{+/+}$mice exhibiting greater locomotor activity on subsequent MA treatment trials than Taar $1^{m 1 J / m 1 J}$ mice, were not found for the MALDR and MAHDR lines (16). Although it is possible that this difference is related to Taarl genotype, existing studies indicate that mice without Taar1 function would be more likely to exhibit the greater stimulant response (see section Other examples of single gene identification for addiction-related traits), opposite to our finding. However, differences in those studies were found for higher doses of MA. It is possible that a genetic background difference played a role in the current outcome. Dose-response studies and studies in the other KI and control lines would benefit interpretation.

\section{Genetic Background Effects}

Previous data support an impact of Taar1 genotype on MA intake and other MA-related traits in multiple mouse models, derived from the DBA/2J and C57BL/6 strains that served as the progenitors of the MADR lines (22). Because many polymorphisms differentiate these strains, more definitive attribution of a trait difference to the Taarl SNP is provided by KI models in which the SNP is specifically manipulated. Thus, we generated multiple CRISPR-Cas 9 KI models to provide conclusive evidence of the impact of the Taar1 SNP and examine potential genetic background effects. In addition, robust effects were observed when the mutant Taar1 allele was replaced with the reference allele in MAHDR mice (21), but we did not know whether such robust effects would be observed for the reciprocal manipulation. Results for MA intake and preference aligned with Taar1 genotype across all of the KI models. Thus, Taar $1^{m 1 J / m 1 J}$ mice of both MAHDR and DBA/2J backgrounds consumed more MA and exhibited greater MA preference than their Taar $1^{+/+}$controls [see (21) and Table 2]. Likewise, results for MA treatment-induced temperature changes were aligned with Taar1 genotype across all of the KI models, with Taar $1^{+/+}$ controls exhibiting hypothermic responses that did not occur in Taar $1^{m 1 J / m 1 J}$ mice [see (20) and Table 2]. 
Although there were similar general outcomes, there were some qualitative differences in results across the models. Because MA intake data for the DBA/2J and C57BL/6 genetic backgrounds were not collected simultaneously, they could not be subjected to direct comparative analysis, but some observations may be worth noting. The effect of exchanging the reference Taar1 allele with the mutant allele in C57BL/6J mice was an increase in MA intake that peaked at about $14 \mathrm{mg} / \mathrm{kg}$ for the $80 \mathrm{mg} / \mathrm{L} \mathrm{MA}$ concentration, whereas the DBA/2J mice, which naturally possess the mutant Taarl genotype consumed about $10 \mathrm{mg} / \mathrm{kg} \mathrm{MA}$ at the $80 \mathrm{mg} / \mathrm{L}$ concentration. Furthermore, the MA intake of mice possessing the Taar $1^{+/+}$genotype on the C57BL/6J vs. DBA/2J background was $5 \mathrm{mg} / \mathrm{kg}$, compared to $3 \mathrm{mg} / \mathrm{kg}$, for the highest MA concentration. This may indicate that there are other genetic variants promoting MA intake in the $\mathrm{C} 57 \mathrm{BL} / 6 \mathrm{~J}$ strain even in the presence of the protective Taar $1^{+/+}$genotype. This is supported by somewhat higher MA preference in Taar $1^{+/+}$mice of the C57BL/6 J background. However, the lower overall MA preference of mice with the Taar $1^{+/+}$genotype, compared to those with the Taar $1^{m 1 J / m 1 J}$ genotype, was clear on both backgrounds. In previous studies, results were compared under identical conditions for DBA/2J and MAHDR mice for MA intake in a binge drinking procedure and for the effect of binge-level drinking followed by withdrawal on depression-like outcomes. MAHDR mice consumed almost twice as much MA as DBA/2J mice. In addition, MAHDR mice displayed greater depression-like symptoms after withdrawal, which may have been related to their higher MA intake (33). Higher MA intake of the MAHDR mice, compared to the DBA/2J, could be due to the presence of C57BL/6J alleles in the MAHDR mice that are permissive for MA intake.

Another apparent difference found in the current studies was a greater reduction over time in body temperature of saline-treated C57BL/6J mice, compared to DBA/2J mice, during isolate housing. This did not impact our ability to detect MAinduced hypothermia, because that effect tends to be most robust within the first $30 \mathrm{~min}$ after administration, but it did clearly demonstrate the ability of MA treatment to inhibit the progressive reduction in body temperature.

Rarely have we found sex differences that interact with line in our previous studies of MA-related traits. A significant line $\times$ sex $x$ time interaction was observed in the examination of MA effects on body temperature in the DBA/2J KI and control line study, but not the C57BL/6J study. Examination of the patterns of response in Figures 7, 8 indicate a strong similarity in male DBA/2J mice with the overall outcome for the C57BL/6J mice. However, female DBA-Taar $1^{+/+}$KI mice had a markedly prolonged hypothermic response to the $2 \mathrm{mg} / \mathrm{kg}$ dose of MA that is more reminiscent of our previous data in MALDR mice (20) and the MAHDRTaar1 ${ }^{+/+}$KI mice (21), although sex differences were not found in those studies. We have speculated that greater sensitivity to hypothermic drug effects may be protective against further drug intake and drug toxicity, and could serve as a marker for reduced psychostimulant addiction risk $(25,34,35)$. Additional data are needed to determine if this is a replicable finding worth pursuing.

\section{Other Examples of Single Gene Identification for Addiction-Related Traits}

The successful identification of single gene effects on complex traits, including addiction-related phenotypes, is increasing. Drug-induced stimulation has been of considerable focus, because feelings of stimulation or euphoria in humans appear to contribute to the potential for escalated use (36). Recent data confirmed Hnrnph1 as a quantitative trait gene for sensitivity to MA-induced stimulation (37). Similar to the way in which Taar1 was identified, Hnrnph1 was first implicated in a quantitative trait locus analysis (38), and then gene editing was used to produce a deletion in the first coding exon of the gene and substantiate its role. Not only did this deletion reduce sensitivity to MA stimulation, it also decreased MA-induced reinforcement, reward and dopamine release (39). It is of interest that MAinduced stimulation also tends to be greater in Taar $1^{\mathrm{m} 1 \mathrm{~J} / \mathrm{m} 1 \mathrm{~J}}$ and Taar1 knock-out mice, both of which lack TAAR1 function and consume more MA or exhibit greater MA reward and reinforcement $(16,18,20,40-43)$. Another study focused on a region of the cannabinoid-1 receptor gene associated with drug and alcohol addiction (44, 45). Deletion using CRISPR-Cas9 technology reduced expression of the cannabinoid-1 receptor in the hippocampus and also reduced alcohol intake (46). Thus, in recent years, several addiction-relevant genes have been identified using genetic mapping and rapid deletion and KI techniques.

The Taar1 SNP is a spontaneously occurring mutation that arose in the JAX DBA/2J mice between 2001 and 2003 (22). Such mutations are not rare. For example, a single base pair deletion arose in intron 3 of the $\mathrm{C} 57 \mathrm{BL} / 6 \mathrm{~J}$ Gabra2 gene adjacent to a splice acceptor site that results in global reduction of mRNA and protein level expression, compared to levels found in other inbred mouse strains. When CRISPR-Cas 9 was used to repair the deletion, mRNA and protein levels were restored (47). GABRA2 variation has been implicated in alcoholism and drug abuse in human populations (48-52). It is possible that this gene also plays a role in the high alcohol consumption found in C57BL/6J mice, compared to many other strains [e.g., $(53,54)]$.

Finally, based on previous data supporting an association of the glutamate receptor subunit gene, ionotropic N-methyld-aspartate 3A (GRIN3A), with nicotine dependence, 16 SNPs were examined in a Chinese Han population. A single SNP association was identified and gene editing was performed in cultured cells using CRISPR-Cas 9 to demonstrate a regulatory function impacting mRNA and protein expression that could be related to differential susceptibility to nicotine dependence (55). The obvious question arises as to whether human TAAR1 variants impact risk for MA addiction. In the mouse, a key feature of Taar1 involvement in MA intake appears to be initial sensitivity to adverse effects of MA, such as conditioned aversion and hypothermia. In fact, the MALDR mice bred for low MA intake consume a comparable amount the first time MA is offered, precipitously reducing their intake in the next drinking session, presumably after experiencing negative subjective effects $(42,56)$. The predictive outcome of negative first experiences with amphetamines have not often been studied in humans, 
although there are a few laboratory-based studies. The general outcome for acute amphetamine and methylphenidate, the two drugs most studied in healthy non-addicted young adults, have documented variation in ratings of arousal, liking and anxiety. Most report positive mood effects, but some report unpleasant effects, and these outcomes predict subsequent session choices of whether or not to take the drug again [see (36)]. None of this research has examined genetic relationships. A recent study by Loftis et al. (57) identified a synonymous TAAR1 SNP that was associated with higher MA craving in individuals with active MA dependence and in remission, compared to controls with no history of substance dependence. When examined in cell culture, cells transfected with this variant had $40 \%$ higher TAAR1 protein expression, compared to cells transfected with the wild-type allele, but no change in protein function. It would be interesting to test this variant in a rodent model of MA craving.

\section{Potential Shortcomings and Limitations of the Current Work}

MA consumption was measured slightly differently at JAX in the $\mathrm{DBA} / 2 \mathrm{~J}$ and $\mathrm{C} 57 \mathrm{BL} / 6 \mathrm{~J} \mathrm{KI}$ and control mice, compared to the way in which it was measured in our previous studies of the MADR lines and MAHDR KI and controls at the VAPORHCS. At JAX, mice were given access to MA for $24 \mathrm{~h}$ /day vs. the $18 \mathrm{~h}$ /day established procedure at the VAPORHCS. The JAX method is procedurally simpler, since bottles do not need to be manipulated during the course of the day, as they do for the 18 $\mathrm{h}$ /day procedure. Although this reduces our ability to directly compare MA intake amounts across studies conducted at the two locations, there is no issue with evaluating genotype effects using either procedure, as can be seen here and in our data for the MAHDR KI and control mice (21). In fact, a previous study found that MA intake was lower when offered to MAHDR mice for $24 \mathrm{~h}$ /day, compared to $18 \mathrm{~h}$ /day, but that the difference in MA intake between MAHDR and MALDR mice remained robust (58).

Our MA-induced conditioned place preference, conditioned taste aversion and hypothermia studies examined the effects of only a single MA dose in each case. The dose used was chosen from previous dose-response studies to reliably produce the effects examined here $(16,18,20,27)$. Furthermore, we have found mice with the Taar $1^{m 1 J / m 1 J}$ genotype to be insensitive to the aversive and hypothermic effects of a wide range of MA doses $(20,27)$; thus, we do not believe that testing additional doses would change the general outcome of the associations described here. Likewise, mice possessing the Taar ${ }^{+}$allele have exhibited little to no sensitivity to rewarding or reinforcing effects of MA $(16,42)$.

Our KI mice are produced by separate breeding pairs from those that produce our control mice; thus, the mice are not littermates. However, that is also the case for all mice that possess each of these genotypes, with the exception of noninbred crosses. For example, the Taar $1^{m 1 J}$ mutation is found in homozygous form in $\mathrm{DBA} / 2 \mathrm{~J}$ mice and in some strains of the $\mathrm{C} 57 \mathrm{BL} / 6 \mathrm{~J} \times \mathrm{DBA} / 2 \mathrm{~J}$ recombinant inbred $(\mathrm{BXD} \mathrm{RI})$ series $(21,22,24,25) . \mathrm{F} 2$ crosses of these mice result in the 3 possible Taar 1 genotypes: Taar $1^{+/+}$, Taar $1^{+/ m 1 J}$, Taar $1^{m 1 J / m 1 J}$. Taar1 genotype-phenotype correlations for MA intake in F2 mice, raised with mixed Taar1 genotypes among littermates, are comparable to those for MADR line individuals and BXD RI strains (22).

\section{CONCLUSIONS AND FUTURE DIRECTIONS}

The Taar 1 SNP at position 229 accounts for $60 \%$ of the genetic variance in MA intake in the selectively bred MADR lines $(19,21)$. Additional research is underway to identify other genes that impact MA intake, including the identification of relevant gene networks [e.g., $(15,19)]$. Variance in MA intake in mice with functional TAAR1 is low, whereas variance in mice lacking TAAR1 function is high $(17,22)$. Data herein and in our published papers indicate that TAAR1 agonist effects of MA are aversive, and we hypothesize that these effects mask rewarding MA effects, strongly inhibiting MA intake. Greater knowledge about the mechanisms by which TAAR1 agonism induces aversion could be leveraged to identify more efficacious treatments for methamphetamine addiction. Because TAAR1 is located intracellularly, MA must be transported into the cell, for example by the dopamine transporter, to gain access. TAAR1 is localized to distinct cellular compartments and signals through different $\mathrm{G} \alpha$ proteins. Thus, cytoplasmic TAAR1 signals via Gos and adenylyl cyclase, whereas TAAR1 localized to the endoplasmic reticulum signals via $\mathrm{G} \alpha 13$, stimulating the GTPase, RhoA (59). The involvement of these different mechanisms in different aspects of TAAR1 effects is currently unknown, as is the circuitry underlying TAAR1 agonist-induced aversion. The lateral habenula (LHb) encodes negative prediction errors and punishment signals, and $\mathrm{LHb}$ activation results in aversive behaviors (60-62). Further, acute MA induces expression of the immediate early gene, fos (63), and lesions of the $\mathrm{LHb}$ increase amphetamine-induced stimulation (64). Based on data indicating that glutamate-mediated synaptic plasticity differentiates the MADR lines (15), and data demonstrating differences between the MADR lines in glutamate responses to MA $(65,66)$, future studies are planned to examine TAAR1 regulation of glutamate synapses in ventral tegmental area dopamine neurons and dorsal raphe serotonin neurons, arising from LHb afferents (67).

Because mice that lack functional TAAR1 are deficient in the opposing aversion mechanism, they have the capacity to experience MA reward. Individual variability in the strength of the rewarding effect may be responsible for residual variability in MA intake in the MAHDR line. Another source of individual variability is genetic modifiers of the Taar $^{m 1 J}$ effect in homozygous individuals. We are examining this in the heterogeneous stock-collaborative cross mice developed by our collaborator, Dr. Robert Hitzemann, at the VAPORHCS, which are the product of an 8-way cross of mouse strains representing $89 \%$ of the genetic variability present in mice $(68,69)$. We recently reported the successful selective breeding of mice for higher and lower amounts 
of MA intake from a population of individuals that are all homozygous for the Taar $1^{m 1 J}$ allele (70). These lines will allow us to perform transcriptome analyses to identify genetic differences that result in resistance to the enhancing effect of the homozygous Taar $1^{m 1 J}$ genotype on MA intake, information that could lead to the identification of a new class of therapeutics.

We previously found that although Oprm1 is not a quantitative trait gene for MA intake (71), it serves as a hub when added to a network of differentially expressed genes derived from nucleus accumbens, prefrontal cortex and ventral midbrain samples from the MALDR and MAHDR lines (19). We confirmed herein that Taarl does not impact sensitivity to morphine-induced hypothermia; rather, Oprm1 likely underlies differential sensitivity to this morphine effect in the MADR lines. This may also be the case for the differential morphine intake of the MADR lines (28), though we have not yet examined this trait in the KI mice. Buprenorphine reduced MA intake in MAHDR mice without impacting total fluid consumption. Lower doses were effective, but higher doses known to have $\mu$-opioid receptor antagonist effects were ineffective, as was the $\mu$-opioid receptor antagonist, naltrexone (28). Morphine, on the other hand, reduced MA intake, but also total fluid intake (71). This suggests that a partial agonist could serve as a treatment to reduce MA intake. To determine whether Oprm1 plays a role in the effectiveness of buprenorphine, we intend to test BXD RI strain mice that have the high MA intake Taar ${ }^{m 1 J / m 1 J}$ genotype, but are homozygous for either the DBA/2J or C57BL/6J Oprm1 allele. If Oprm1 allele is irrelevant, than effects on MA intake should be comparable across strains.

Finally, it should be noted that Taar1 agonists and partial agonists are being explored as therapeutics for MA addiction and other neuropsychiatric conditions (72), and have shown promise in animal models (73-75). Of course, the strategy of increasing TAAR1-mediated activity with direct agonists requires a functional receptor, and thus, is not an approach we have been able to take in our genetic mouse models of absent TAAR1 function. However, we have collected data in mice possessing the Taar $^{+}$allele, and confirmed that TAAR1-specific agonists have strong aversive effects (Shabani and Phillips, unpublished data). It is possible that TAAR1 agonists reduce MA intake via a substitution mechanism (75), but also possible that agonists activate aversion circuitry that reduces the potency of MA reward. We are not aware of reports directly characterizing the subjective effects of TAAR1 agonists in humans.

\section{REFERENCES}

1. Barkley-Levenson AM, Cunningham CL, Smitasin PJ, Crabbe JC. Rewarding and aversive effects of ethanol in High Drinking in the Dark selectively bred mice. Addict Biol. (2015) 20:80-90. doi: 10.1111/adb.12079

2. Cunningham CL. Genetic relationships between ethanol-induced conditioned place aversion and other ethanol phenotypes in 15 inbred mouse strains. Brain Sci. (2019) 9:209. doi: 10.3390/brainsci9080209

3. Fritz BM, Cordero KA, Barkley-Levenson AM, Metten P, Crabbe JC, Boehm $\mathrm{SL}$, et al. Genetic relationship between predisposition for binge alcohol consumption and blunted sensitivity to adverse effects of alcohol in mice. Alcohol Clin Exp Res. (2014) 38:1284-92. doi: 10.1111/acer.12385

\section{DATA AVAILABILITY STATEMENT}

The original contributions presented in the study are included in the article/Supplementary Materials, further inquiries can be directed to the corresponding author/s.

\section{ETHICS STATEMENT}

The animal study was reviewed and approved by Institutional Animal Care and Use Committee of the VA Portland Health Care System, Portland, OR or the Institutional Animal Care and Use Committee of The Jackson Laboratory, Bar Harbor, ME.

\section{AUTHOR CONTRIBUTIONS}

TP: experimental design, development of mouse models, statistical analysis, data interpretation, and manuscript writing and revision. TR, SA, HB, JE, and JM: data acquisition, entry, and verification of accuracy. CR: development of experimental protocols, supervision of technical staff, statistical analysis, figure preparation, drafting of methods and results, and manuscript editing. EC: experimental design, development of mouse models, and manuscript editing. All authors contributed to the article and approved the submitted version.

\section{FUNDING}

The funding sources for this research were NIH NIDA U01 DA041579 and R01 DA046081 (TP, SA, HB, JE, and CR), P50 DA018165 (TP, HB, JE, and CR), P50 DA039841 (EC and TR), and T32DA007262 (JM); NIH NIAAA R24 AA020245 (TP, JE, and CR); Department of Veterans Affairs I01 BX002106 (TP and JE) and the VA Research Career Scientist Program (TP).

\section{ACKNOWLEDGMENTS}

The authors gratefully acknowledge the assistance of the Scientific Services at The Jackson Laboratory, in particular Genetic Engineering Technology service.

\section{SUPPLEMENTARY MATERIAL}

The Supplementary Material for this article can be found online at: https://www.frontiersin.org/articles/10.3389/fpsyt. 2021.725839/full\#supplementary-material

4. Rhodes JS, Ford MM, Yu CH, Brown LL, Finn DA, Garland T Jr, et al. Mouse inbred strain differences in ethanol drinking to intoxication. Genes Brain Behav. (2007) 6:1-18. doi: 10.1111/j.1601-183X.2006.00210.x

5. Davidson C, Lee TH, Ellinwood EH. Acute and chronic continuous methamphetamine have different long-term behavioral and neurochemical consequences. Neurochem Int. (2005) 46:189203. doi: 10.1016/j.neuint.2004.11.004

6. Narita M, Miyatake M, Shibasaki M, Tsuda M, Koizumi S, Narita $\mathrm{M}$, et al. Long-lasting change in brain dynamics induced by methamphetamine: enhancement of protein kinase C-dependent astrocytic response and behavioral sensitization. J Neurochem. (2005) 93:1383-92. doi: 10.1111/j.1471-4159.2005.03097.x 
7. Nishioku T, Shimazoe T, Yamamoto Y, Nakanishi H, Watanabe S. Expression of long-term potentiation of the striatum in methamphetamine-sensitized rats. Neurosci Lett. (1999) 268:81-4. doi: 10.1016/S0304-3940(99)00386-9

8. Pierce RC, Kalivas PW. A circuitry model of the expression of behavioral sensitization to amphetamine-like psychostimulants. Brain Res Brain Res Rev. (1997) 25:192-216. doi: 10.1016/S0165-0173(97)00021-0

9. Richetto J, Feldon J, Riva MA, Meyer U. Comparison of the longterm consequences of withdrawal from repeated amphetamine exposure in adolescence and adulthood on information processing and locomotor sensitization in mice. Eur Neuropsychopharmacol. (2013) 23:160-70. doi: 10.1016/j.euroneuro.2012.04.005

10. Robinson TE, Becker JB, Presty SK. Long-term facilitation of amphetamineinduced rotational behavior and striatal dopamine release produced by a single exposure to amphetamine: sex differences. Brain Res. (1982) 253:23141. doi: 10.1016/0006-8993(82)90690-4

11. Schmidt ED, Tilders FJ, Binnekade R, Schoffelmeer AN, De Vries TJ. Stressor- or drug-induced sensitization of the corticosterone response is not critically involved in the long-term expression of behavioural sensitization to amphetamine. Neuroscience. (1999) 92:343-52. doi: 10.1016/S0306-4522(98)00725-8

12. Schmidt ED, Schoffelmeer AN, De Vries TJ, Wardeh G, Dogterom G, Bol JG, et al. A single administration of interleukin-1 or amphetamine induces longlasting increases in evoked noradrenaline release in the hypothalamus and sensitization of ACTH and corticosterone responses in rats. Eur J Neurosci. (2001) 13:1923-30. doi: 10.1046/j.0953-816x.2001.01569.x

13. Tenn CC, Kapur S, Fletcher PJ. Sensitization to amphetamine, but not phencyclidine, disrupts prepulse inhibition and latent inhibition. Psychopharmacology (Berl). (2005) 180:36676. doi: 10.1007/s00213-005-2253-z

14. Vanderschuren LJ, Schmidt ED, De Vries TJ, Van Moorsel CA, Tilders FJ, Schoffelmeer AN. A single exposure to amphetamine is sufficient to induce long-term behavioral, neuroendocrine, and neurochemical sensitization in rats. J Neurosci. (1999) 19:9579-86. doi: 10.1523/JNEUROSCI.19-21-09579.1999

15. Hitzemann R, Iancu OD, Reed C, Baba H, Lockwood DR, Phillips TJ. Regional analysis of the brain transcriptome in mice bred for high and low methamphetamine consumption. Brain Sci. (2019) 9:155. doi: 10.3390/brainsci9070155

16. Shabani S, McKinnon CS, Reed C, Cunningham CL, Phillips TJ. Sensitivity to rewarding or aversive effects of methamphetamine determines methamphetamine intake. Genes Brain Behav. (2011) 10:625-36. doi: 10.1111/j.1601-183X.2011.00700.x

17. Shabani S, Houlton SK, Hellmuth L, Mojica E, Mootz JR, Zhu Z, et al. A mouse model for binge-level methamphetamine use. Front Neurosci. (2016) 10:493. doi: 10.3389/fnins.2016.00493

18. Wheeler JM, Reed C, Burkhart-Kasch S, Li N, Cunningham CL, Janowsky A, et al. Genetically correlated effects of selective breeding for high and low methamphetamine consumption. Genes Brain Behav. (2009) 8:75871. doi: 10.1111/j.1601-183X.2009.00522.x

19. Belknap JK, McWeeney S, Reed C, Burkhart-Kasch S, McKinnon CS, $\mathrm{Li} \mathrm{N}$, et al. Genetic factors involved in risk for methamphetamine intake and sensitization. Mamm Genome. (2013) 24:44658. doi: 10.1007/s00335-013-9484-9

20. Harkness JH, Shi X, Janowsky A, Phillips TJ. Trace amine-associated receptor 1 regulation of methamphetamine intake and related traits. Neuropsychopharmacology. (2015) 40:2175-84. doi: 10.1038/npp.2015.61

21. Stafford AM, Reed C, Baba H, Walter NA, Mootz JR, Williams RW, et al. Taar1 gene variants have a causal role in methamphetamine intake and response and interact with Oprm1. Elife. (2019) 8:e46472. doi: 10.7554/eLife.46472.022

22. Reed C, Baba H, Zhu Z, Erk J, Mootz JR, Varra NM, et al. A spontaneous mutation in Taarl impacts methamphetamine-related traits exclusively in DBA/2 mice from a single vendor. Front Pharmacol. (2018) 8:993. doi: 10.3389/fphar.2017.00993

23. Keane TM, Goodstadt L, Danecek P, White MA, Wong K, Yalcin B, et al. Mouse genomic variation and its effect on phenotypes and gene regulation. Nature. (2011) 477:289-94. doi: 10.1038/nature10413

24. Shi X, Walter NA, Harkness JH, Neve KA, Williams RW, Lu L, et al. Genetic polymorphisms affect mouse and human trace amine-associated receptor 1 function. PLoS One. (2016) 11:e0152581. doi: 10.1371/journal.pone.0152581
25. Mootz JRK, Miner NB, Phillips TJ. Differential genetic risk for methamphetamine intake confers differential sensitivity to the temperaturealtering effects of other addictive drugs. Genes Brain Behav. (2020) 19:e12640. doi: 10.1111/gbb.12640

26. Phillips TJ, Shabani S. An animal model of differential genetic risk for methamphetamine intake. Front Neurosci. (2015) 9:327. doi: $10.3389 /$ fnins. 2015.00327

27. Shabani S, McKinnon CS, Cunningham CL, Phillips TJ. Profound reduction in sensitivity to the aversive effects of methamphetamine in mice bred for high methamphetamine intake. Neuropharmacology. (2012) 62:113441. doi: 10.1016/j.neuropharm.2011.11.005

28. Eastwood EC, Phillips TJ. Morphine intake and the effects of naltrexone and buprenorphine on the acquisition of methamphetamine intake. Genes Brain Behav. (2014) 13:226-35. doi: 10.1111/gbb.12100

29. Eastwood EC, Phillips TJ. Opioid sensitivity in mice selectively bred to consume or not consume methamphetamine. Addict Biol. (2014) 19:3709. doi: $10.1111 / \mathrm{adb} .12003$

30. Gubner NR, Reed C, McKinnon CS, Phillips TJ. Unique genetic factors influence sensitivity to the rewarding and aversive effects of methamphetamine versus cocaine. Behav Brain Res. (2013) 256:420-7. doi: 10.1016/j.bbr.2013.08.035

31. Doyle GA, Furlong PJ, Schwebel CL, Smith GG, Lohoff FW, Buono RJ, et al. Fine mapping of a major QTL influencing morphine preference in C57BL/6 and DBA/2 mice using congenic strains. Neuropsychopharmacology. (2008) 33:2801-9. doi: 10.1038/npp.2008.14

32. Doyle GA, Schwebel CL, Ruiz SE, Chou AD, Lai AT, Wang MJ, et al. Analysis of candidate genes for morphine preference quantitative trait locus Mop2. Neuroscience. (2014) 277:403-16. doi: 10.1016/j.neuroscience.2014.07.020

33. Shabani S, Schmidt B, Ghimire B, Houlton SK, Hellmuth L, Mojica E, et al. Depression-like symptoms of withdrawal in a genetic mouse model of binge methamphetamine intake. Genes Brain Behav. (2019) 18:e12533. doi: 10.1111/gbb.12533

34. Miner NB, Elmore JS, Baumann MH, Phillips TJ, Janowsky A. Trace amineassociated receptor 1 regulation of methamphetamine-induced neurotoxicity. Neurotoxicology. (2017) 63:57-69. doi: 10.1016/j.neuro.2017.09.006

35. Miner NB, Phillips TJ, Janowsky A. The role of biogenic amine transporters in trace amine-associated receptor 1 regulation of methamphetamine-induced neurotoxicity. J Pharmacol Exp Ther. (2019) 371:36-44. doi: 10.1124/jpet.119.258970

36. de Wit H, Phillips TJ. Do initial responses to drugs predict future use or abuse? Neurosci Biobehav Rev. (2012) 36:156576. doi: 10.1016/j.neubiorev.2012.04.005

37. Ruan QT, Yazdani N, Reed ER, Beierle JA, Peterson LP, Luttik KP, et al. $5^{\prime}$ UTR variants in the quantitative trait gene Hnrnphl support reduced $5^{\prime}$ UTR usage and hnRNP $\mathrm{H}$ protein as a molecular mechanism underlying reduced methamphetamine sensitivity. FASEB J. (2020) 34:922344. doi: 10.1096/fj.202000092R

38. Yazdani N, Parker CC, Shen Y, Reed ER, Guido MA, Kole LA, et al. Hnrnph1 is a quantitative trait gene for methamphetamine sensitivity. PLoS Genet. (2015) 11:e1005713. doi: 10.1371/journal.pgen.1005713

39. Ruan QT, Yazdani N, Blum BC, Beierle JA, Lin W, Coelho MA, et al. A mutation in Hnrnphl that decreases methamphetamineinduced reinforcement, reward, and dopamine release and increases synaptosomal hnRNP H and mitochondrial proteins. J Neurosci. (2020) 40:107-30. doi: 10.1523/JNEUROSCI.1808-19.2019

40. Lindemann L, Meyer CA, Jeanneau K, Bradaia A, Ozmen L, Bluethmann $\mathrm{H}$, et al. Trace amine-associated receptor 1 modulates dopaminergic activity. J Pharmacol Exp Ther. (2008) 324:948-56. doi: 10.1124/jpet.107.132647

41. Miller GM. The emerging role of trace amine-associated receptor 1 in the functional regulation of monoamine transporters and dopaminergic activity. J Neurochem. (2011) 116:164-76. doi: 10.1111/j.1471-4159.2010.07109.x

42. Shabani S, Dobbs LK, Ford MM, Mark GP, Finn DA, Phillips TJ. A genetic animal model of differential sensitivity to methamphetamine reinforcement. Neuropharmacology. (2012) 62:2169-77. doi: 10.1016/j.neuropharm.2012.01.002

43. Wolinsky TD, Swanson CJ, Smith KE, Zhong H, Borowsky B, Seeman $\mathrm{P}$, et al. The trace amine 1 receptor knockout mouse: an animal model with relevance to schizophrenia. Genes Brain Behav. (2007) 6:62839. doi: 10.1111/j.1601-183X.2006.00292.x 
44. Chen X, Williamson VS, An SS, Hettema JM, Aggen SH, Neale MC, et al. Cannabinoid receptor 1 gene association with nicotine dependence. Arch Gen Psychiatry. (2008) 65:816-24. doi: 10.1001/archpsyc.65.7.816

45. Pava MJ, Woodward JJ. A review of the interactions between alcohol and the endocannabinoid system: implications for alcohol dependence and future directions for research. Alcohol. (2012) 46:185-204. doi: 10.1016/j.alcohol.2012.01.002

46. Hay EA, McEwan A, Wilson D, Barrett P, D'Agostino G, Pertwee RG, et al. Disruption of an enhancer associated with addictive behaviour within the cannabinoid receptor-1 gene suggests a possible role in alcohol intake, cannabinoid response and anxiety-related behaviour. Psychoneuroendocrinology. (2019) 109:104407. doi: 10.1016/j.psyneuen.2019.104407

47. Mulligan MK, Abreo T, Neuner SM, Parks C, Watkins CE, Houseal $\mathrm{MT}$, et al. Identification of a Functional Non-coding Variant in the GABA (A) Receptor $\alpha 2$ subunit of the C57BL/6J mouse reference genome: major implications for neuroscience research. Front Genet. (2019) 10:188. doi: 10.3389/fgene.2019.00188

48. Agrawal A, Edenberg HJ, Foroud T, Bierut LJ, Dunne G, Hinrichs AL, et al. Association of GABRA2 with drug dependence in the collaborative study of the genetics of alcoholism sample. Behav Genet. (2006) 36:64050. doi: 10.1007/s10519-006-9069-4

49. Enoch MA, Schwartz L, Albaugh B, Virkkunen M, Goldman D. Dimensional anxiety mediates linkage of GABRA2 haplotypes with alcoholism. Am J Med Genet B Neuropsychiatr Genet. (2006) 141b:599-607. doi: 10.1002/ajmg.b.30336

50. Lappalainen J, Krupitsky E, Remizov M, Pchelina S, Taraskina A, Zvartau E, et al. Association between alcoholism and gamma-amino butyric acid $\alpha 2$ receptor subtype in a Russian population. Alcohol Clin Exp Res. (2005) 29:493-8. doi: 10.1097/01.ALC.0000158938.97464.90

51. Li D, Sulovari A, Cheng C, Zhao H, Kranzler HR, Gelernter J. Association of gamma-aminobutyric acid A receptor $\alpha 2$ gene (GABRA2) with alcohol use disorder. Neuropsychopharmacology. (2014) 39:90718. doi: 10.1038/npp.2013.291

52. Villafuerte S, Strumba V, Stoltenberg SF, Zucker RA, Burmeister M. Impulsiveness mediates the association between GABRA2 SNPs and lifetime alcohol problems. Genes Brain Behav. (2013) 12:525-31. doi: 10.1111/gbb.12039

53. Belknap JK, Crabbe JC, Young ER. Voluntary consumption of ethanol in 15 inbred mouse strains. Psychopharmacology (Berl). (1993) 112:50310. doi: 10.1007/BF02244901

54. Yoneyama N, Crabbe JC, Ford MM, Murillo A, Finn DA. Voluntary ethanol consumption in 22 inbred mouse strains. Alcohol. (2008) 42:14960. doi: 10.1016/j.alcohol.2007.12.006

55. Chen J, Liu Q, Fan R, Han H, Yang Z, Cui W, et al. Demonstration of critical role of GRIN3A in nicotine dependence through both genetic association and molecular functional studies. Addict Biol. (2020) 25:e12718. doi: 10.1111/adb.12718

56. Eastwood EC, Barkley-Levenson AM, Phillips TJ. Methamphetamine drinking microstructure in mice bred to drink high or low amounts of methamphetamine. Behav Brain Res. (2014) 272:11120. doi: 10.1016/j.bbr.2014.06.035

57. Loftis JM, Lasarev M, Shi X, Lapidus J, Janowsky A, Hoffman WF, et al. Trace amine-associated receptor gene polymorphism increases drug craving in individuals with methamphetamine dependence. PLoS One. (2019) 14:e0220270. doi: 10.1371/journal.pone.0220270

58. Stafford AM, Reed C, Phillips TJ. Non-genetic factors that influence methamphetamine intake in a genetic model of differential methamphetamine consumption. Psychopharmacology (Berl). (2020) 237:3315-36. doi: 10.1007/s00213-020-05614-9

59. Underhill SM, Hullihen PD, Chen J, Fenollar-Ferrer C, Rizzo MA, Ingram SL, et al. Amphetamines signal through intracellular TAAR1 receptors coupled to $\mathrm{G} \alpha(13)$ and $\mathrm{G} \alpha(\mathrm{S})$ in discrete subcellular domains. Mol Psychiatry. (2021) 26:1208-23. doi: 10.1038/s41380-019-0469-2

60. Hikosaka O. The habenula: from stress evasion to value-based decisionmaking. Nat Rev Neurosci. (2010) 11:503-13. doi: 10.1038/nrn2866

61. Matsumoto M, Hikosaka O. Lateral habenula as a source of negative reward signals in dopamine neurons. Nature. (2007) 447:1111-5. doi: 10.1038/nature05860
62. Matsumoto M, Hikosaka O. Two types of dopamine neuron distinctly convey positive and negative motivational signals. Nature. (2009) 459:83741. doi: $10.1038 /$ nature 08028

63. Wirtshafter D, Asin KE, Pitzer MR. Dopamine agonists and stress produce different patterns of Fos-like immunoreactivity in the lateral habenula. Brain Res. (1994) 633:21-6. doi: 10.1016/0006-8993(94)91517-2

64. Gifuni AJ, Jozaghi S, Gauthier-Lamer AC, Boye SM. Lesions of the lateral habenula dissociate the reward-enhancing and locomotorstimulant effects of amphetamine. Neuropharmacology. (2012) 63:945-57. doi: 10.1016/j.neuropharm.2012.07.032

65. Lominac KD, Quadir SG, Barrett HM, McKenna CL, Schwartz LM, Ruiz PN, et al. Prefrontal glutamate correlates of methamphetamine sensitization and preference. Eur J Neurosci. (2016) 43:689-702. doi: 10.1111/ejn.13159

66. Szumlinski KK, Lominac KD, Campbell RR, Cohen M, Fultz EK, Brown CN, et al. Methamphetamine addiction vulnerability: the glutamate, the bad, and the ugly. Biol Psychiatry. (2017) 81:959-70. doi: 10.1016/j.biopsych.2016.10.005

67. Quina LA, Tempest L, Ng L, Harris JA, Ferguson S, Jhou TC, et al. Efferent pathways of the mouse lateral habenula. J Comp Neurol. (2015) 523:3260. doi: $10.1002 / \mathrm{cne} .23662$

68. Iancu OD, Darakjian P, Walter NA, Malmanger B, Oberbeck D, Belknap $J$, et al. Genetic diversity and striatal gene networks: focus on the heterogeneous stock-collaborative cross (HS-CC) mouse. BMC Genomics. (2010) 11:585. doi: 10.1186/1471-2164-11-585

69. Roberts A, Pardo-Manuel de Villena F, Wang W, McMillan L, Threadgill DW. The polymorphism architecture of mouse genetic resources elucidated using genome-wide resequencing data: implications for QTL discovery and systems genetics. Mamm Genome. (2007) 18:473-81. doi: 10.1007/s00335-0079045-1

70. Reed C, Stafford AM, Mootz JRK, Baba H, Erk J, Phillips TJ. A breeding strategy to identify modifiers of high genetic risk for methamphetamine intake. Genes Brain Behav. (2021) 20:e12667. doi: 10.1111/gbb. 12667

71. Eastwood EC, Eshleman AJ, Janowsky A, Phillips TJ. Verification of a genetic locus for methamphetamine intake and the impact of morphine. Mamm Genome. (2018) 29:260-72. doi: 10.1007/s00335-017-9724-5

72. Dodd S, Carvalho AF, Puri BK, Maes M, Bortolasci CC, Morris G, et al. Trace amine-associated receptor 1 (TAAR1): a new drug target for psychiatry? Neurosci Biobehav Rev. (2021) 120:537-41. doi: 10.1016/j.neubiorev.2020.09.028

73. Cotter R, Pei Y, Mus L, Harmeier A, Gainetdinov RR, Hoener M, et al. The trace amine-associated receptor 1 modulates methamphetamine's neurochemical and behavioral effects. Front Neurosci. (2015) 9:39. doi: 10.3389/fnins.2015.00039

74. Liu J, Wu R, Li JX. TAAR1 and psychostimulant addiction. Cell Mol Neurobiol. (2020) 40:229-38. doi: 10.1007/s10571-020-00792-8

75. Pei Y, Asif-Malik A, Hoener M, Canales JJ. A partial trace amineassociated receptor 1 agonist exhibits properties consistent with a methamphetamine substitution treatment. Addict Biol. (2017) 22:1246-56. doi: $10.1111 / \mathrm{adb} .12410$

Conflict of Interest: The authors declare that the research was conducted in the absence of any commercial or financial relationships that could be construed as a potential conflict of interest.

Publisher's Note: All claims expressed in this article are solely those of the authors and do not necessarily represent those of their affiliated organizations, or those of the publisher, the editors and the reviewers. Any product that may be evaluated in this article, or claim that may be made by its manufacturer, is not guaranteed or endorsed by the publisher.

Copyright (c) 2021 Phillips, Roy, Aldrich, Baba, Erk, Mootz, Reed and Chesler. This is an open-access article distributed under the terms of the Creative Commons Attribution License (CC BY). The use, distribution or reproduction in other forums is permitted, provided the original author(s) and the copyright owner(s) are credited and that the original publication in this journal is cited, in accordance with accepted academic practice. No use, distribution or reproduction is permitted which does not comply with these terms. 